\title{
Mereology in Kalām
}

\section{A New Reading of the Proof from Accidents for Creation}

\author{
Ayman Shihadeh \\ s OAS University of London, London, U K \\ and New York University Abu Dhabi, Abu Dhabi, UAE \\ a.shihadeh@soas.ac.uk
}

\begin{abstract}
The objective of this article is twofold. First, it investigates mereology in medieval Islamic theology, particularly the theologians' claim that the whole is identical to its parts and accordingly that at least some attributes common to the parts must by extension be attributed of the whole. This claim was refuted by philosophers and, from the eleventh century onwards, an increasing number of theologians. Second, it offers a new interpretation of the standard theological proof from accidents for creation ex nihilo, to which this problem was central. A wide range of early, classical and later theological and philosophical sources are consulted.
\end{abstract}

\section{Keywords}

mereology - proof from accidents for creation ex nihilo - Abū l-Hudhayl al-'Allāf Yahyā ibn 'Adī - Avicenna - Mu'tazilism - Ash'arism - Abū l-Ḥusayn al-Bașrī - alMalāḥimī - Fakhr al-Dīn al-Rāzī

This article investigates a previously unknown debate on mereology, which was played out between theologians and their adversaries and among theologians starting from the second/eighth century. ${ }^{1}$ The debate turned on the theolog-

1 I am grateful to the anonymous reviewer for comments on an earlier draft, and to the Humanities Research Fellowship programme at New York University Abu Dhabi for affording me the opportunity to complete this study. A note on convention: Arabic book titles are introduced with an accompanying English translation only if they are of intrinsic interest to the discussion. Most titles are not. 
ical view that the whole is identical to its parts and accordingly that at least some attributes common to the parts are also attributes of the whole. Theologians of both the Mu'tazilī and Ash'arī schools defended this principle in the course of arguing for the creation of the world ex nihilo through the well-known proof from accidents, in which it served as a direct route to the createdness of the world starting from the createdness of its parts. This mereological line of reasoning was refuted by their philosopher critics, most notably the eternalist Avicenna (d. 428/1037), as well as an increasing number of theologians from the fifth/eleventh century onwards, including Abū l-Ḥusayn al-Bașrī (d. 436/1044), Fakhr al-Dīn al-Rāzì (d. 6o6/1210) and Ibn Taymiyya (d. 728/1328). By revealing the crucial role that mereology played in the proof from accidents, our study will offer a new account both of the proof itself and of its historical development. Against the current view that the proof initially suffered from a serious logical flaw, which was not rectified until the fifth/eleventh century, we shall argue that this flaw in fact never existed.

\section{The Proof from Accidents: Background}

Introduced by the early Bașran Mu'tazilī Abū l-Hudhayl al-'Allāf (d. 227/841) and grounded in his atomist ontology, the proof from accidents (dalïl al-a'rādu) was the first fully-fledged proof for creation ex nihilo in kaläm. ${ }^{2}$ But it was also the most successful proof, as it is attested in a wide range of sources across the full spectrum of theological schools in the classical period and continued to be one of the most important and ubiquitous proofs for this doctrine in later theology. In its earlier form, the proof consists of four theses, termed "contentions" $\left(d^{\prime} w \bar{a}\right)$ by the Bașran Mu'tazila and "principles" (așl) by Ash'arīs:

1. The affirmation of accidents (ithbāt al-a'räd), which is to say that they exist. Accidents are superadded objects $(m a n \bar{a})$ that inhere in atoms.

2. Accidents are originated (hudüth or hadath al-a'rạ̈̂).

2 The proof is attributed to him, for instance, by al-Qāḍi 'Abd al-Jabbār, al-Mughnī fì abwāb al-tawhīd wa-l-'adl, 8. al-Makhlūq, ed. by Tawfīq al-Ṭawīl and Sa'īd Zāyid (Cairo: al-Dār almișriyya li-l-ta'līf wa-l-tarjama, 1965), 286; Abū Rashīd al-Nīsābūrī, Ziyādāt al-Sharh, ed. by Muhammad 'A. Abū Rīda (Cairo: al-Mu’assasa al-mișriyya al-āmma li-l-ta'līf wa-l-tarjama wal-ṭibā'a wa-l-nashr, 1969), 101; Ibn Mattawayh, al-Tadhkirafíahkāmal-jawāhirwa-l-a'rāụ, ed. by Daniel Gimaret, 2 vols (Cairo: Institut français d' archéologie orientale, 2009), 1, 31; Mānkdīm, Sharh al-uṣūl al-khamsa, ed. by 'Abd al-Karīm 'Uthmān (Cairo: Maktabat Wahba, 1965), 95; cf. Josef van Ess, Theology and Society in the Second and Third Centuries of the Hijra, tr. by Gwendolin Boldblum (Leiden: Brill, 2017), 3, 248-50. 
3. Atoms (or bodies) cannot be devoid (yata'arrā, yanfakku, yakhlū) of, and hence cannot pre-exist, accidents. ${ }^{3}$

4. Because they do not pre-exist accidents, which are originated, atoms (or bodies) too must be originated.

It follows that the world, being the combination of all atoms and accidents, is created in time, out of nothing. Each of these theses is supported with evidence, and is susceptible to objections, or what theologians describe as "specious arguments" (sg. shubha), which tend to be addressed thoroughly in longer texts, and less so or not at all in shorter ones. It will be noted that the proof, as its philosopher critics complained, lacks a familiar syllogistic structure. After all, classical kaläm did not have recourse to syllogistic logic, and it was only under the influence of philosophical logic that later versions of the proof came to be formulated as a syllogism: ${ }^{4}$

1. Bodies cannot be devoid of accidents.

2. Accidents are originated things.

3. Therefore, bodies cannot be devoid of originated things.

4. What cannot be devoid of originated things is itself originated.

5. Therefore, bodies are originated.

In what follows, however, we shall reference the classical, four-thesis formulation. The structure of the proof has little bearing on the problem at hand.

In the present paper, we are solely concerned with how the fourth thesis is defended. The thesis is inferred from the second and third theses thus: because atoms do not pre-exist accidents, and because accidents are originated, atoms too must be originated. Therefore, because it is the totality of all atoms and accidents, the world came to be in time, ex nihilo. Qualifying the assertion that 'atoms do not pre-exist accidents,' classical-kalām sources explain that what an atom does not pre-exist is only the very first accident that supervened thereon. It is hence this initial accident, rather than subsequent accidents or the entirety of accidents, that constitutes the evidence (dalil) proper for the createdness of atoms, even though this initial accident is individually unknowable to us, as we know neither the ab initio locations of atoms nor the time of their coming to be. ${ }^{5}$

3 In some sources, this appears as the second thesis.

4 Ayman Shihadeh, "The Argument from Ignorance and Its Critics in Medieval Arabic Thought," Arabic Sciences and Philosophy 23 (2013): 171-220, at 173-5; Abū l-Ḥusayn al-Bașrī, Ghurar aladilla, in Ibn Taymiyya, Dar' ta'ārud al-'aql wa-l-naql, ed. by Muhammad R. Sālim, 11 vols (Riyadh: Jāmicat al-Imām Muḥammad ibn Sacūd al-islāmiyya, 1991), 9, 134; al-Ghazālī, alIqtișād fíl-i'tiqāẹ, ed. by Ibrāhīm A. Çubukçu and Hüseyin Atay (Ankara: Nur matbaasi, 1962), 26 ff.; Fakhr al-Dīn al-Rāzī, Nihāyat al-'uqūl fì dirāyat al-ușūl, ed. by Sa'ìd 'A. Fūda, 5 vols (Beirut: Dār al-dhakhāir, 2015), 1, $223 \mathrm{ff}$.

5 Anonymous 1, in Al-Ṣaḥib ibn 'Abbād Promoter of Rational Theology: Two Mu'tazil̄̄ kalām Texts 
Although, at first glance, the fourth thesis may seem to have been adequately substantiated through the second and third, it is nonetheless susceptible to an objection, indeed the most serious objection raised against the proof from accidents. As one source puts it, this is where the real battle begins, as it is the point at which the doctrine of creation ex nihilo comes into direct conflict with eternalist cosmologies. ${ }^{6}$ Various medieval philosophers, including Ibn Suwār (d. after 407/1017), Abū l-Barakāt al-Baghdādì (d. before 56o/1164-5) and Averroes (d. 595/1198), objected that theologians cannot help themselves to the fourth thesis so easily, because the second thesis states that each accident is originated, whereas the fourth thesis presupposes a further thesis - namely, that, as well as each being originated, past accidents are also quantitatively finite. Thus far, the quantitative finitude of past accidents remains unsubstantiated, leaving the fourth thesis susceptible to the objection that the series of past originated things is beginningless (hawädith lä awwala la-hāa). ${ }^{7}$ This I shall henceforth refer to simply as the infinite regress thesis. If $\mathrm{A}_{1}-\mathrm{A}_{\mathrm{n}}$ are all the accidents that supervened in succession on a given atom $\left(A_{1}\right.$ being the most recent) such that each accident passed away as a new one came to be, and if each of these accidents is originated, and if atoms cannot be devoid of accidents, then this atom cannot pre-exist the very first accident that supervened thereon. Critics objected that even if the first three theses of the proof are admitted, it will nonetheless be conceivable that every accident that came to be in an atom was preceded by another accident ad infinitum, $\mathrm{A}_{1}-\mathrm{A}_{\infty}$, and accordingly that there was no initial accident $A_{n}$, whose host atom could not pre-exist. Atoms, on this scenario, would be pre-eternal. Averroes famously deems this a fatal flaw in the proof, and opines that it was only addressed by "later" theologians, by whom he means

from the Cairo Geniza, ed. by Wilferd Madelung and Sabine Schmidtke (Leiden: Brill, 2017), 35-6 (the first of the two texts published in this book consists of fragments of an unidentified fourth/tenth-century Bahshamī source; why the editors gloss over this fact and make no attempt to justify the attribution to Ibn 'Abbād is beyond me); Abū Rashīd, Ziyāāāt, 236; al-Malāhimì̄, al-Fä̉iq fì ușūl al-dīn, ed. by Wilferd Madelung and Martin McDermott (Tehran: Iranian Institute of Philosophy, 2007), 11; al-Juwaynī, al-Shāmil fì uṣūl al-dīn, ed. by 'Alī S. alNashshār, Fayṣal B. 'Awn and Suhayr M. Mukhtār. (Alexandria: Munsha’at al-ma‘̄āif, 1969), 221-2.

6 Al-Harrāsī, Ușūl al-dīn, Ms Cairo, Dār al-kutub al-miṣriyya, kalām 29o, fol. $5^{2}$; also cited by Ibn Taymiyya, Dar', 1, 95.

7 For instance, Ibn Suwār, Maqāla fì anna dalìl Yahya al-Naḥwì 'alā ḥadath al-'álam awlā bil-qabül min dalïl al-mutakallimin așlan, in al-Aflātūniyya al-muḥdatha 'inda l-'arab, ed. by 'Abd al-Raḥmān Badawī (Kuwait: Wikālat al-mațbū'āt, 1977), 243-7, at 244-5; Abū l-Barakāt al-Baghdādī, al-Mu'tabarfí l-hikma, ed. by 'Abdallāh al-'Alawī al-Ḥaḍramī et al., 3 vols (Hyderabad: Dā’irat al-macārif al-'uthmāniyya, 1357 AH ), 3, 31-2; Averroes, al-Kashf 'an manāhij aladilla fí 'aqā'id al-milla. ed. by Muḥammad 'A. al-Jābirī (Beirut: Markaz dirāsāt al-waḥda al'arabiyya, 1998), 109-10. 
the Ash'arī theologian al-Juwaynī (d. 478/1085), who supposedly supplemented the proof with arguments for the impossibility of a beginningless series of accidents. ${ }^{8}$

This account of the history of the proof from accidents has by and large been accepted in recent scholarship. Herbert Davidson argues that earlier kaläm theologians failed to substantiate the fourth thesis and that the proof was "left at that" until the Mu'tazilī 'Abd al-Jabbār (d. 415/1025) supplemented it with arguments for the impossibility of a beginningless series of accidents. ${ }^{9}$ Following Averroes, he identifies al-Juwaynī as a key figure who developed a new version of the proof by substituting the fourth thesis of the older version with the thesis that a beginningless series of originated things is impossible, and he remarks that al-Juwaynī claims credit for this new version. ${ }^{10}$

In this article, however, we show that this standard account is off the mark. Early theologians, indeed from as early as Abū l-Hudhayl himself, were in fact confronted by the infinite regress problem and addressed it in defence of the fourth thesis. The main argument they adduced in this defence was grounded in what I shall term the mereological principle, which in its developed form states that an attribute common to the parts is also an attribute of their totality. A rudimentary version is attested in Abu l-Hudhayl, the more developed version in numerous classical and later theological sources.

\section{Mereology in the Proof from Accidents: I. Abū l-Hudhayl al-'Allāf}

Abu l-Hudhayl, to start with, was evidently aware of the challenge posed by the infinite regress problem, which most likely arose in discussions he reportedly had with eternalists (dahriyya). He acknowledged that this problem would vitiate proofs for both the creation of bodies ex nihilo and consequently the existence of the Creator. ${ }^{11}$ His solution to the problem invoked the concepts 'part' (ba'd), 'entirety' (jamī) and 'whole' (kull), a theme to which he report-

8 Averroes, Kashf, 110.

9 Herbert A. Davidson, Proofs for Eternity, Creation, and the Existence of God in Medieval Islamic and Jewish Philosophy (New York: Oxford University Press, 1987), 143-6 at 143. Daniel Gimaret likewise contends that the fourth thesis was defended only through arguments for the impossibility of a beginningless series of accidents (La doctrine d'al-Ash'ari [Paris: Cerf, 2007], 225-7). The present author also accepted Averroes's account in a previous publication ("Existence of God," in The Cambridge Companion to Classical Islamic Theology, ed. by Tim Winter [Cambridge: Cambridge University Press, 20o8], 197-217, at 205-6).

10 Davidson, Proofs, 146.

11 Al-Khayyāț, Kitāb al-Intișār, ed. by Albert N. Nader (Beirut: al-Mațba'a al-kathūlīkiyya, 
edly gave much attention in discussions of creation ex nihilo. ${ }^{12}$ (Throughout this paper, Arabic and English words denoting totalities in so far as they are totalities are treated as synonyms, as their semantic nuances have no impact on the ideas dealt with here.) There is ample evidence that he adduced an early version of the mereological principle, which goes something like this: if multiple things share the same attribute they will have a totality, and all that has a totality must be quantitatively finite.

Abū l-Hudhayl, first of all, contends that originated things (muhdathät) have "a whole and totality."13 Accidents have a totality and make up a single whole, whereas atoms make up a different whole. ${ }^{14}$ The same is true of accidents of the same class; the totality of motion accidents, for instance, constitute a single whole. We can infer from these examples that for a set of items to make up a totality, they must all share the same attribute. Motions have a totality on account of being motions, and so do atoms on account of being atoms. On account of being originated all atoms and accidents make up a larger totality of originated things. The arguments he adduced for this contention are reported tersely and rather opaquely in the available sources. They include this reductio ad absurdum. Whenever parts aggregate, they constitute a whole, because if an aggregation of parts were not a whole, a whole need not be aggregated of parts, which is impossible. ${ }^{15}$ The argument presupposes the coextensiveness of the definition of 'whole' as 'the aggregation of parts.'16 The terse report does

1957), 18. Abū l-Hudhayl is reported to have debated the proof from accidents with eternalists (al-Murtaḍā, Amālī, ed. by Muḥammad A. Ibrāhīm, 2 vols [Cairo: 'T̄sā al-Bābī al-Ḥalabī, 1954], 1, 181).

12 The early Mu'tazilī al-Khayyāt (d. ca. 30o/913) describes discussions "of what existed in the past and will exist in the future, of the whole and the part, and of the finite and the infinite" as "a major principle" in theology and a difficult topic which Abū l-Hudhayl discussed often (al-Khayyāț, Intișār, 18; 15; cf. al-Ka'bī, Kitāb Maqālāt, ed. by Hüseyin Hansu, Rājị̣ Kurdī and 'Abd al-Ḥamīd Kurdī [Istanbul: Kuramer, 2018], 163; al-Ash'arī, Maqālāt al-islämiyyìn, ed. by Helmut Ritter [Wiesbaden: Franz Steiner, 1980], 1, 485; 163). This connects mereology to questions of the temporal finitude of the world and the quantitative finitude of things a part ante and a parte post. Abū l-Hudhayl's priority was to prove creation ex nihilo, but he was forced to concede that because originated things are quantitatively finite a parte ante, they must likewise be quantitatively finite a parte post. The details are of little relevance here. See van Ess, Theology, 3, $276 \mathrm{ff}$.

13 Al-Khayyāț, Intișār, 16; cf. 91.

14 Al-Khayyāț, Intișār, 20.

15 Al-Khayyāt, Intișār, $16-7$.

16 On this criterion of definition, see Robert Brunschvig, "Ǧāmi 'Mānic," in Études d'islamologie, ed. by Abdel Magid Turki, 2 vols (Paris: Éditions Larose, 1976), 2: 355-7. Another argument is that when I say, 'no motions are rocks,' I pass a judgement on the totality of motions, not on individual motions; therefore, motions have a totality (al-Khayyāț, Intișār 20-1). 
not spell out how Abū l-Hudhayl justified this position. It is fairly easy to see how the notion that an aggregation of parts may not constitute a whole could be problematic, but it is less obvious how this view would entail that not all wholes need be aggregated of parts.

Abū l-Hudhayl furthermore held that a totality must be quantitatively finite, although the fragmentary statements attributed to him shed little light on how he arrived at this view. All we can gather is that he appears convinced that a whole must have a limit (ghāya), or an end (nihāya). ${ }^{17}$ It is likely that he thought that for something to be a totality it must encompass all its parts, and that for something to encompass a set of items it must have boundaries beyond which none of those items are present. It would follow that a totality must be quantitatively finite. ${ }^{18}$

That Abū l-Hudhayl applied his early version of the mereological principle to prove the creation of the world ex nihilo is evident. ${ }^{19}$ By virtue of sharing the attribute of being originated, originated things - the past and present constituents of the world-have a totality and are therefore quantitatively finite. God by contrast has neither parts nor a totality, and is therefore not finite. With this, the second, third and fourth theses of Abül-Hudhayl's four-step proof from accidents for creation ex nihilo fall into place. If, as per the second thesis, each accident comes to be in time, then all accidents will share the quality of being originated and thereby must have a totality and hence be quantitatively finite, which is to say that they must thus have a beginning in time. And because atoms cannot be devoid of accidents, they cannot pre-exist the totality of accidents. The arguer can then deduce the fourth thesis, that if the totality of past accidents have a beginning in time, and if atoms do not pre-exist the totality of accidents, then atoms too must be originated, which is to say that all atoms come to be in time. Therefore, the world is created ex nihilo.

\section{Mereology in the Proof from Accidents: II. Classical Kalām}

Abū l-Hudhayl's primitive mereological argument, to my knowledge, is nowhere deployed in extant later sources; no subsequent theologian would argue

\footnotetext{
17 Al-Khayyāț, Intișār, 16-7.

18 As supplementary evidence, Abū l-Hudhayl further adduced Qurānic texts that refer to "everything" (kull shay'), which he interpreted as indicating that things have a whole (lil-ashy $\bar{a}^{\prime}$ kull), which is encompassed in God's knowledge; and what is encompassed must be finite (al-Khayyāt, Intișār, 17 , citing Q. $2.29 ; 16.77 ; 41.54 ; 72.28$ ). This is a grammatically unjustifiable reading, as kull in these Quraanic citations has the sense of 'each,' not 'all.' 
simply from the homogeneity of multiple items to their quantitative finitude. To the contrary, it is widely accepted that a totality may, in principle, comprise either a finite or an infinite quantity of items. ${ }^{20}$ In Bașran Mu'tazilism and classical Ash'arism, we encounter a more developed appeal to mereology, through which an attribute is extended from the parts to the whole. This principle, henceforth termed the mereological principle, goes as follows:

If multiple things share the same attribute $x$, they will have a totality, and $x$ will itself be attributed of this totality.

This unqualified, universally applicable formulation of the principle is encountered in more concise instances of the proof from accidents typically found in shorter theological works, and it is most likely the earliest, primitive formulation of the principle. In longer, more detailed instances of the proof from accidents, the principle is restricted to necessary attributes, to the exclusion of possible attributes: only if $x$ is a necessary attribute of each part will $x$ be attributed of their totality. We shall return to this qualification in Section 5 .

When the mereological principle is applied to accidents with respect to their shared attribute of 'being originated' (hâadith), it gives us what, in the context of the proof from accidents, I shall term simply the mereological argument:

Because accidents share the attribute of being temporally initiated, they have a totality, and their totality too is temporally initiated.

'Temporally initiated' here corresponds to the expression 'having a beginning' (lahu awwal), which is widely attested in the sources. In the case of the totality of a series of accidents, 'the beginning' will refer to the initial accident in the series. However, in the case of an individual accident, it will refer to the temporal beginning of its existence, which is the moment of its comingto-be. The latter notion is often expressed more accurately as 'the accident having a beginning to its existence' (li-wujüdihi awwal). For some sources, however, awwal strictly speaking means 'first thing,' and is hence used literally in the former sense, and only figuratively (maja $\bar{z}$ ) and to an extent unsatisfactorily in the latter. ${ }^{21}$ Although both senses are said to reduce to the

20 For instance, Abū Rashīd, Ziyādāt, 239-40. Two later thinkers who denied that a totality could be infinite are the sixth/twelfth-century colleagues Ibn Ghaylān al-Balkhī (Hudūth al-'ālam, ed. by Mahdi Mohaghegh [Tehran: Mu’assasa-i muțālacāt-i islāmī, 1998], 26) and Sharaf al-Dīn al-Mas'ūdī (Ayman Shihadeh, Doubts on Avicenna: A Study and Edition of Sharaf al-Dìn al-Mas'üdìs Commentary on the Ishārāt [Leiden: Brill, 2016], 151ff.). 
same concept of 'the subject's being temporally preceded by its non-existence' (whether the subject is a thing or a totality), we shall later on see how this dual sense was found problematic by many.

The earliest known occurrence of the developed version of the mereological argument is attested in the beginning of a lost work titled al-Masāil al'askarìyāt by Abū Hāshim al-Jubbā'i (d. 321/933), the eponymous founder of the Bahshamī branch of Bașran Mu'tazilism. He reportedly countered the infinite regress thesis by arguing that if we postulate a beginningless series of past originated things, those things will have a totality (jumla), or a whole (kull). And although this totality is infinite, it will nonetheless be a knowledge-object for us, presumably because each of its parts is an actual or possible knowledgeobject for us; ${ }^{22}$ so because the totality is a knowledge-object, we are able to determine properties thereof, specifically whether it could be, as postulated, beginningless. ${ }^{23} \mathrm{Abu}$ Hāshim argues that this postulate involves a contradiction (tanāqud), because a totality cannot be temporally beginningless when each of its parts $\left(b a^{c} d\right)$ has a temporal beginning. The postulate would be just as contradictory as it would be to assert that a body is at once both moving and immobile. Being impossible, such contradictions can only be committed verbally, but never express a mentally conceivable state of affairs (yaqa u fi l'ibārāt dūn al-itiqādāt wa-l-madhāhib). ${ }^{24}$ In Abū Hāshim's version of the mereological argument, the principle that an attribute shared by the units must be an attribute of their totality is strongly implied but not explicitly stated.

This line of reasoning was developed further by Abū Hāshim's followers, the Bahshamis, most of whom considered it to be the main defence of the fourth thesis of the proof from accidents, so much so that one source identifies the mereological principle as the only belief whose denial would hold one up from inferring the fourth thesis from the preceding theses. ${ }^{25}$ The prin-

22 They are all actual knowledge-objects for God. However, the argument is obviously made from our (human) perspective.

23 I render 'ilm, in the sense of a discrete item of knowledge (as opposed to a body of knowledge), as 'knowledge-item', and ma'lūm as 'knowledge-object'. Correspondingly, maqdūr is rendered as 'power-object'.

24 Anonymous 1, 51; Abū Rashīd, Zìyādāt, 239-40; Ibn Mattawayh, al-Majmū' fì l-Muhịt bi-ltaklīf, ed. by 'Umar S. 'Azmī (Cairo: al-Dār al-mișriyya lil-ta'līf wa-l-tarjama, 1965), 1, 67-8; al-Jishumī, Sharh 'Uyūn al-masā̉il, Ms Sanaa, al-Jāmi' al-kabīr, al-Maktaba al-gharbiyya, foll. $178^{\mathrm{b}}-179^{\mathrm{a}}$.

25 Ibn Mattawayh writes that a second misbelief that would have the same result is that an atom may pre-exist accidents; however, this is already addressed in the third thesis $\left(\right.$ Majmū $\left.^{\prime}, 1,66\right)$. An exception among Bahshamīs is Abū 'Abdallāh al-Bașrī (d. 369/980), who relied on a different argument in support of the fourth thesis, though he did not reject the mereological argument (Majmǘc, 1, 68-9). 
ciple is adduced, for instance, by a fourth/tenth-century Bahshamī, who argues as follows:

If it is established that each one [of a set of things] is originated, then their entirety $(j a m \bar{\imath})$ too must be originated. It is impossible that they all be originated, and yet have no beginning; for describing them as originated excludes the view that they have no beginning. ${ }^{26}$

He adds that "it is impossible for an attribute to be affirmed for individual things, but negated of their whole, as this would be a contradiction." ${ }^{27}$ Likewise, the influential 'Abd al-Jabbār defends the fourth thesis by saying that the notion of a beginningless series of accidents involves a contradiction,

[...] because each one of them has a beginning. It is therefore impossible for their entirety not to have a beginning, because originatedness is true of them all. Therefore, because their whole must have a beginning, and because a body cannot be devoid of their entirety, it must be originated, just as it would be if it had not been devoid of a single originated thing. ${ }^{28}$

The same argument occurs in other fifth/eleventh-century Bahshamī sources, including Abū Rashīd al-Nīsābūrī (d. ?), Ibn Mattawayh (d. ?), Yahyyā ibn alḤusayn al-Buṭ̣̂ānī (d. 424/1033) and al-Ḥākim al-Jishumī (d. 494/1101), as well as in theologically Mu'tazilī Imāmī sources, such as al-Murtaḍā (d. 436/1044) and al-Karājakī (d. 449/1057). ${ }^{29}$ The argument is also adduced by the non-

26 Anonymous $1,56-7$.

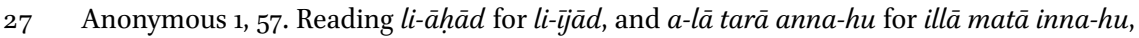
and fa-kawn for yakūna (which does not fit with ithbāt), and omitting the editors' interpolations (yașiḥ̂u, bi-an, qüla) (ll. 12-14).

28 Al-Qāạī 'Abd al-Jabbār, al-Mukhtașar fì uṣūl al-dīn, in Rasāil al-'adl wa-l-tawhīd, ed. by Muḥammad 'Amāra, 2 vols (Cairo: Dār al-shurūq, 1988), 1: 197-282, at 206 (reading ka-an for kāna); cf. al-Buțhānī, Ziyāāāt Sharh al-ușūl, ed. by Camila Adang, Wilferd Madelung and Sabine Schmidtke (Leiden: Brill, 2011), 45 (citing 'Abd al-Jabbār); al-Murtaḍā, alMulakhkhaș fì ușūl al-dīn, ed. by Muḥammad R. Qummī (Tehran: Markaz-i nashr-i dānishgāhī, 2002), 55 (where the same equation is made between the body being devoid of multiple originated things and it being devoid of a single originated thing).

29 Abū Rashīd, Ziyādāt, 239-43; Ibn Mattawayh, Majmūú, 1, 67; al-Buț̣̄ān̄, Ziyādāt, 45-6; alJishumī, Sharh, foll. 178 $8^{\mathrm{b}}-179^{\mathrm{a}}$; Anonymous 2, Sharh Kitāa al-Tadhkira fì ahkām al-jawāhir wa-l-a'rā d, facsimile edition with introduction by Sabine Schmidtke (Tehran: Iranian Institute of Philosophy, 2006), foll. 13 $3^{\mathrm{a}-\mathrm{b}}$; al-Karājakī, Kanz al-fawā’id, ed. by 'Abdallāh Ni'ma, 2 vols (Beirut: Dār al-aḍwā', 1985), 1, 40-1. For al-Murtaḍā, see the previous note and p. 25 below. 
Bahshamī Bașran Mu'tazilī Abū l-Ḥusayn al-Bașrī in his earlier manual Ghurar al-adilla, where he argues for the finitude of the series of past accidents as follows: "Because each originated item has a beginning, it is impossible for their entirety $($ jam $\tau$ ) not to have a beginning, as [the whole] is nothing but its individual units." ${ }^{30}$ As we shall see, Abū l-Husayn's position on the mereological principle shifts in a later work.

Classical Ashariss too support the fourth thesis in the same way. Adducing Abū Hāshim's version of the argument in his commentary on Abū l-Ḥasan alAsh'arī's (d. 324/936) Luma', al-Bāqillānī (d. 403/1013) remarks that this is the clearest (aqrab) argument against the infinite regress of past originated things. Originated things, he says, have a "whole and entirety," and it would be contradictory to assert that each has a beginning to its existence whereas the totality is beginningless. ${ }^{31} \mathrm{Al}-\mathrm{Bāq}$ illānī is also reported by al-Kiyā al-Harrāsī (d. 504/1110) to have argued that an originated thing must, by definition, have a beginning to its existence. So,

If all originated things are taken in combination (dummat) with each other so that they are an aggregate $\left(\mathrm{jam}^{c}\right)$, their reality will not change. Because an originated thing has a beginning, so too must multiple originated things have beginnings, as the reality does not change with aggregation. ${ }^{32}$

In the fifth/eleventh and early sixth/twelfth century, the same line of reasoning is attested in 'Abd al-Qāhir al-Baghdādī (d. 429/1038), al-Māwardī (d. 450/1058), al-Juwaynī and Abū l-Qāsim al-Anșāīi (d. 512/1118), who writes: "A totality is an aggregate of individuals; and if the reality of an individual originated thing is that it has a beginning, then the reality of multiple originated things is that they have a beginning." ${ }^{33}$ The argument is also adduced by the (non-Ash'arī) theologian Ibn Hazm (d. 456/1064) in his own proof for creation ex nihilo. ${ }^{34}$

30 Abū l-Ḥusayn, Ghurar, in Ibn Taymiyya, Dar', 9, 137; cf. 8, 18. I render hāädith in this case as 'originated item' because Abū l-Ḥusayn denied that accidents were objects.

31 Al-Bāqillānī, Sharh al-Luma', in Ibn Taymiyya, Dar', 8, 340-1.

32 Al-Harrāsī, Ușūl, fol. $53^{\text {b. }}$.

33 Al-Anșārī, al-Ghunya fíl-kalām, ed. by Mușțafā Ḥ. 'Abd al-Hādī, 2 vols (Cairo: Dār al-salām, 2010), 1, 317; cf. Abū Manșūr 'Abd al-Qāhir al-Baghdādī, Ușūl al-dīn (Istanbul: Madrasat alilāhiyyāt bi-dār al-funūn al-turkiyya, 1928), 59-6o; al-Māwardī, A'lām al-nubuwwwa (Beirut: Dār al-kutub al-'ilmiyya, 1986), 10; al-Juwayn̄̄, Luma'al-adilla fí qawā'id 'aqā’id ahl al-sunna wa-l-jamā'a, ed. by Fawqiyya Ḥ. Maḥmūd (Beirut: 'Ālam al-kutub, 1987), 90 (occurring only in the earlier version of the book, cited here); al-Juwaynī, Shāmil, 216-7.

34 Ibn Ḥazm, al-Fișal fì l-milal wa-l-ahwā’ wa-l-nihal, ed. by Muhammad I. Naṣr and 'Abd alRaḥmān 'Umayra, 5 vols (Beirut: Dār al-jīl, 1996), 1, 57-8. 
Theologians support the mereological principle in two ways. ${ }^{35}$ Some consider it self-evident, and accordingly infer the fourth thesis immediately from the second and third. This explains its absence in some of the more concise iterations of the proof from accidents. Others hold that the principle must be deduced through arguments. Abū Hāshim al-Jubbā'ī appears to have taken the former position with respect to his early version of the principle, as our sources suggest that he did not feel the need either to defend or to refine it. In other sources, the principle is supported, as is often the case in classical kaläm, with analogies, typically with identically-coloured bodies: if each crow is black, the totality of crows will be black. ${ }^{36}$ Other examples are adduced. If each individual is existent, male or an unbeliever, then their totality will be, respectively, existent, male or unbelieving. We shall further investigate theological defences of the mereological principle in Section 5 , our concern in the present section being how it was formulated and applied.

It is abundantly evident, therefore, that the mereological argument was widely adduced in support of the fourth thesis of the proof from accidents. It was in fact considered the principal and most direct route to securing this thesis, because it involved simply the affirmation of the attribute of the parts to their whole, in contrast to arguments against the infinite regress thesis, which typically postulated this thesis and reduced it to absurdity, thus proving creation ex nihilo indirectly. To the theologians themselves, the mereological argument fulfilled its task satisfactorily, in as much as the principal objective of kalām was to afford rational substantiation to a set of theological doctrines. At the same time, however, they knew that the argument was sorely insufficient for dialectical purposes, and that much more work was needed to refute the infinite regress thesis, which was given impetus and thrust into the mainstream of kalām by the vocal contrarian Ibn al-Rāwandī in his Kitāb al-Tāj. ${ }^{37}$ The fourth

35 For instance, Abū Rashīd takes the former view (Ziyādāt, 231 ff.), whereas Ibn Mattawayh takes the latter (Majmū, $\left.65^{-6}\right)$.

36 Anonymous 1, 57; Abū l-Ḥusayn, Ghurar, in Ibn Taymiyya, Dar’, 9, 137; Abū Rashīd, Ziyādāt, 242-3; Ibn Mattawayh, Majmū', 59; al-Jishumī, Sharh, fol. 178º ; al-Buṭhānī, Ziyāāāt, 46; Anonymous 2, Sharh al-Tadhkira, fol. 13a' Abū Ja far al-Ṭūsī, Tamhīd al-uṣūl (Qum: alMarkaz al-takhașșuși li-'ilm al-kalām al-islāmī, 2016), 64. The sources normally analogise to people (zunj) rather than to crows.

37 The infinite regress thesis is frequently ascribed to Ibn al-Rāwandī in fourth/tenth- and fifth/eleventh-century sources (al-Khayyāț, Intișār, 18; 19-20; 21; Anonymous 1, 51; Ibn Mattawayh, Tadhkira, 1, 33; 42; Mānkdīm, Sharh, 113; al-Buṭhānī, Ziyādāt, 9; al-Murtaḍā, Mulakhkhaṣ, 56-7; Abū Ja far al-Ṭūsī, Tamhīd, 63-4; Fakhr al-Dīn al-Rāzī, Ușūl al-Dìn, Ms Beirut, American University of Beirut Library, 297:R27kA, fol. 22a). Ibn al-Rāwandī is also the likeliest target of al-Ka'bī's response to unnamed "godless individuals" (mulhidūn) in the recently published Maqālät, which was completed in 290/903 (577 ff.; for titles of ded- 
thesis of the proof from accidents thus needed to be defended with much more than the mereological argument. For this reason, the four-step proof from accidents is normally appended with a dedicated discussion typically titled, "On the impossibility of a beginningless series of originated things (hawädith la

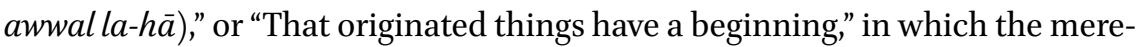
ological argument is set out alongside further, auxiliary arguments.

Averroes's aforementioned account of the history of the proof from accidents for creation ex nihilo, repeated in recent studies, is therefore incorrect. The fourth thesis of the proof was not left undefended by Abū l-Hudhayl and other early theologians, nor was it patched up only when later, fifth/eleventhcentury sources noticed the shortcoming and consequently secured this thesis using arguments against infinite regress. It was in fact supported with the mereological argument from the start. Al-Juwaynī neither developed a substantially new version of the proof from accidents, nor in fact did he claim to do so. ${ }^{38}$ Averroes's view that al-Juwayni was the first theologian to support the fourth thesis stems from his limited access to pre-Juwaynian Ash'arī summae and his complete lack of access to Mu'tazilī texts. ${ }^{39}$ What al-Juwaynī introduced to the proof from accidents was in fact only a comparatively minor structural adjustment, to which the young Fakhr al-Dīn al-Rāzì refers when he writes the following on Ash'arīs:

Our [earlier] school-members count the four principles as the affirmation and originatedness of accidents, the impossibility that atoms be devoid of accidents, and fourthly "that what cannot be devoid of originated things must itself be originated." They then respond to eternalists (azaliyya) in a separate discussion. Later [school-members] count the discussion against eternalists as one of the four principles, and say that it follows from these principles that what cannot be devoid of originated things must itself be originated. ${ }^{40}$

icated responses to Ibn al-Rāwandī by al-Ka'bī, see Racha El Omari, The Theology of $A b \bar{u}$ l-Qāsim al-Balkhī/al-Käbì (d. 319/931) [Leiden: Brill, 2016], 18; 25).

38 Pace Davidson, who says that al-Juwayni takes credit for developing a new version of the proof (Proofs, 14). Al-Juwaynī refers, not to the four-thesis proof, but clearly to one of his arguments against the infinite regress thesis (Shämil, 218-19).

The latter point is admitted in Averroes, Kashf, 118 .

Al-Rāzī, Ușūl, foll. $22^{\mathrm{a}-\mathrm{b}}$. On this text, see Ayman Shihadeh, "Al-Rāzì's Earliest Kalām Work: Eastern Ash'arism in the Twelfth Century," in Philosophical Theology in Islam: Later Ash'arism East and West, ed. by Ayman Shihadeh and Jan Thiele (Leiden: Brill, 2020), 367o. Al-Rāzī in this text follows al-Juwaynī's arrangement. 
As noted, earlier kalām sources generally append the proof from accidents with arguments that bolster its fourth thesis by refuting the eternalist infinite regress thesis. The innovation introduced by al-Juwayni (representing the "later" Ash'arīs mentioned in the passage just quoted) is to incorporate this appendant discussion, which is to say the thesis that "originated things have a beginning" (al-hawādith la-hä awwal), into the proof itself. This becomes the fourth thesis of the proof, replacing the thesis, "Because they do not preexist originated things, atoms must themselves be originated". This last thesis in turn is made the conclusion of the proof, which follows from (tarattaba 'alā, or kharaja min) its four theses. ${ }^{41} \mathrm{Al}$-Juwayn's improved formulation is born of a desire to tighten up the proof: instead of starting by establishing the fourth thesis and then eliminating the eternalist counter-thesis in a subsequent discussion, he does all this in one and the same discussion. That al-Juwayni did not consider this new formulation to be substantively different from the old one is evident in the fact that the two occur, and are treated as identical, in the earlier recension of his Luma ${ }^{c} .42$

Philosophical Refutations of the Mereological Principle: Yahyā ibn 'Adī, Avicenna and Others

Before we turn our attention to theological defences and elaborations of the mereological principle, it behoves us first to examine criticism it aroused among Aristotelian philosophers. There are good historical and analytical reasons for us to start with the criticism before the defence. As mentioned, the principle was initially given a simple formulation and effectively treated as having unqualified, universal applicability. It was subsequently defended and developed within a dialectical milieu, in which theologians honed their argument for creation ex nihilo in response to refutations coming mainly from outside the theological tradition, particularly earlier on from eternalists (dahriyya) and then from philosophers. These refutations raise questions that we ourselves would ask of the principle, and are of the types that we shall consider in the present section-after all, the philosophers to be discussed here refute the mereological principle only in its universal formulation, and do not engage with theological qualifications and defences thereof.

41 Al-Juwaynī, Kitāab al-Irshād ilā qawāți al-adilla fì ușūl al-ítiqād, ed. by Muhammad Mūsā and 'Alī 'Abd al-Ḥamīd (Cairo: Maktabat al-Khānjī, 1950) 17-18; 27; Shāmil, 166; 220.

42 Al-Juwaynī, Luma', 87-8; 9 o. 
With the waning of the earlier Dahrī current, and the ascendancy of Aristotelianism in the fourth/tenth century, the kaläm proof from accidents came under a second wave of attack, this time from the rival tradition of Aristotelian philosophy. Short treatises devoted to refuting the proof were penned by the Christian Aristotelians of Baghdad Yahyā ibn 'Adì (d. 363/974) and his student Ibn Suwār, who adhered to the doctrine of creation ex nihilo but were nonetheless convinced that the proof was in several respects unsound. Without identifying Abū Hāshim al-Jubbā'ì by name, Ibn Suwār responds to his contention that the proof from accidents is the only proof for creation ex nihilo, stressing that by refuting this proof he does not refute the doctrine for which it is adduced. ${ }^{43} \mathrm{He}$ promotes a proof put forth by John Philoponus as a superior alternative. Representing the eternalist strand of Arabic Aristotelianism, Avicenna defends the pre-eternity of the world by mounting a further challenge to proofs for creation ex nihilo and against pre-eternalism, including the proof from accidents. Some of these Aristotelian refutations, especially Ibn 'Adi's and Avicenna's, had a significant impact on subsequent theological versions of the proof from accidents.

The most potent criticisms levelled against the proof from accidents by these two philosophers are those that target its fourth thesis, including refutations of the mereological argument. The Hanbali theologian Ibn Taymiyya, who was keenly interested in the history of the debate, classifies these refutations alongside objections put forth by some theologians into a fourfold taxonomy, in which he draws on Aristotelian logic and the tradition of juristic dialectic ( jadal):44

1. Begging the question. It is objected that the argument begs the question, because it is premised on a mere assertion (mușädara) of its conclusion. Some totalities are such that an attribute common to the parts is extended to the totality-let us call those type-A totalities. Type-B totalities are such that the attribute common to the parts is not extended to their totality. What the mereological argument lacks, according to its critics, is evidence that the totality of objects sharing the attribute of being originated is a type-A totality.

Ibn Taymiyya then turns to the argument from analogy adduced in support of the mereological principle. In classical kaläm, as in jurisprudence, analogy ( qiyās) involves arguing from one particular case, called the primary case (așl), (say, the totality of black crows) to another particular case, called the secondary

43 Ibn Suwār, Maqāla, 243; 245-6. On Abū Hāshim's position, see, for instance, Ibn Mattawayh, Majmǘ, 38; 71 .

Ibn Taymiyya, Dar', 9, 138-9. 
case $\left(\operatorname{far}^{\mathrm{c}}\right)$, (the totality of originated things) without the need to establish a universal statement. In Aristotelian logic, this form of argument, termed qiyās al-tamthil, is described as an argument from particular examples (the totality of black crows) to a universal statement (the mereological principle). Ibn Taymiyya points out that critics countered the analogies adduced by exponents of the mereological argument by pursuing three lines of refutation. As they are taught in the tradition of juristic dialectic (jadal), these types of refutation are standard objections (itirāa ${ }^{\text {) }}$ ) deployable against arguments from analogy: ${ }^{45}$

2. Denial $\left(\operatorname{man}^{\mathrm{c}}\right)$. An analogy starts from a claim identifying the determinant ('illa) on account of which a judgement ( $\mathrm{hukm}$ ) applies to a primary case, where the determinant is a specific description (wasf) of that case. The totality of crows (a primary case) is black (the judgement) because individual crows share the attribute of being black (the determinant). An objector may deny the claim in several ways - for instance, by denying the purported determinant of the judgement, or that the primary and secondary cases share the same description-leaving the burden of proof on the arguer. In effect, this objection to the analogy at hand reduces to the previous objection. It is not attested in any of sources considered here.

3. Counter-evidence (mu'arada). In the second of these analogy-busting procedures, the objector presents counter-examples of cases that match the description of the primary case of an analogy, but clearly do not share its judgement, thereby illustrating the falsity of the universal assertion that the judgement holds for all cases bearing that description.

4. Invalidating difference ( farq). An objector may invalidate an analogy by pointing out a crucial difference between the primary and secondary cases, specifically one or more aspects of the determinant of the judgement that applies to the primary case, which is absent in the description of the secondary case. The judgement consequently does not transfer to the secondary case.

This helpful taxonomy of refutations to the mereological argument will be adopted in our own investigation of the debate.

The third refutation is represented by one of the most widely attested, and probably one of the earliest, objections. ${ }^{46}$ Its source is anonymous, but is unlikely to be a philosopher. Al-Juwaynī attributes it to a "stupid person," con-

45 On these dialectical procedures, see Walter E. Young, The Dialectical Forge: Juridical Disputation and the Evolution of Islamic Law (Cham: Springer, 2017), 152-4; 176-82.

46 Anonymous 1, 57-9; Abū Rashīd, Ziyādāt, 24O-2; Ibn Mattawayh, Majmū̌́, 1, 67; Anonymous 2, Sharh al-Tadhkira, foll. 13 $3^{\mathrm{a}-\mathrm{b}}$; al-Juwaynī, Shämil, 216-17. 
ceivably a reference to Ibn al-Rāwandī. It invokes the doctrine of the infallibility of the Muslim community in cases of consensus $\left(\ddot{j} m \bar{a}^{c}\right)$ : even though each individual believer is fallible, the totality of believers are infallible. Alternatively, it sometimes starts from the notion that widely-transmitted reports (mutawätir) are indubitably authentic, even though individual reports are of limited reliability.

The first and third refutations are typified in a short epistle against the kalām proof from accidents, titled Maqūla fì l-radd 'alā man qāla bi-anna l-ajsām muhdatha (Treatise in Dialectical Refutation of Those Who Say that Bodies are Originated), in which Ibn 'Adī attacks the mereological argument as a sophism (mughälața). ${ }^{47}$ This epistle, as we shall see, had direct impact on theologians. Ibn 'Adī charges that the mereological principle cannot be granted, as its exponents fail to support it with a demonstration. He then counters that there are countless cases in which a property $(\mathrm{hukm})$ shared by the parts in fact does not extend to their whole, and he gives counter-examples. ${ }^{48}$ If we were to divide up ten thousand pounds of lead into one-pound portions, it would be possible for each portion to be lifted by one person, but this would not be possible for the totality. Likewise, when a scribe copies a book, it is possible for him to miss out any part of the book, but impossible for him to miss out the entire book. Because Ibn 'Adī's text is explicitly dialectical in its approach, he deems it sufficient to illustrate the falsity of the theologians' mereological argument without needing to tender his own account of which properties do extend from the parts to the whole and under what conditions. He does this in an unrelated text titled Maqāla fíl-kull wa-l-ajzā (Treatise on the Whole and the Parts). ${ }^{49}$

Avicenna's engagement with the mereological principle is more complex. In one work, he expresses disdain for the proof from accidents remarking that its form is unsound and its premises false. ${ }^{0}$ One reason for this stance comes to the fore in his responses to arguments against the infinite regress thesisarguments which were transmitted in earlier philosophical literature, but more pressingly were being deployed by contemporary theologians in defence of creation ex nihilo. Avicenna's responses occur in discussions on pre-eternity in his general philosophical treatises, most importantly in the Physics of the Shifä

\footnotetext{
47 Yaḥyā ibn 'Adī, Maquăla fì l-radd 'alā man qāla bi-anna l-ajsām muḥdatha, ed. and trans. by Peter Adamson and Robert Wisnovsky in id., "Yahyyā Ibn 'Adī on a Kalām Argument for Creation," Oxford Studies in Medieval Philosophy 5 (2017): 213-39, at 234.

48 Ibn 'Adī, Maqāla fì l-radd, 236.

49 Yaḥyā ibn 'Adī, Maqāla fì l-kull wa-l-ajzāà, ed. by Saḥbān Khulayfāt in id., Maqālāt Yahyā ibn Adī al-falsafiyya (Amman: University of Jordan, 1988), 212-19.

50 Avicenna, al-Ta līqāt, ed. by 'Abd al-Raḥmān Badawī (Cairo: al-Hay’a al-mișriyya al-'āmma li-l-kitāb, 1973), 37.
} 
and the shorter al-Mabda'wa-l-ma'a $\bar{d}$, and they are set out more extensively in a short work titled al-Hukūma fi hujaj al-muthbitīn li-l-mādì mabda' zamānī (The Appraisal of the Arguments of Those Who Affirm a Temporal Beginning to the Past), his dedicated response to a lost work in which John Philoponus offered arguments against the pre-eternity of the world. ${ }^{51}$ Avicenna contends that all these arguments are premised on the notion that past successive occurrences constitute a totality ( jumla), and that they attempt to demonstrate in various ways how it is impossible that this totality be quantitatively infinite. For instance, the well-known correspondence argument states that the series of past successive motions cannot be infinite, because if it is assumed to be infinite, the totality of motions up to the Flood would be smaller than their totality up to our present time; however, an infinite quantity cannot be smaller or greater than another infinite quantity. ${ }^{52}$ Avicenna complains that such arguments treat past occurrences as constituting an existing, realised quantity (kamm hạșil), when in fact such a quantity cannot have an extra-mental reality, as most things that came to be in the past no longer exist..$^{53} \mathrm{~A}$ real totality, as opposed to one depicted in the mind, requires the aggregation $\left(i j t i m \bar{a}^{c}\right)$ of coevally existing things. ${ }^{54}$ This position stems from a position of mathematical realism, according to which quantities have a mind-independent reality as accidents of material substances. ${ }^{55}$

Another argument confuted in the Shifä is the classical-kalām mereological argument: "Because every motion is originated, the whole (kull) and totality (jumla) of motions is originated." ${ }^{26}$ In response, Avicenna says that arguers

51 On which, see Shlomo Pines, Studies in Arabic Versions of Greek Texts and in Medieval Science (Jerusalem: The Magnes Press, 1986), 321-6.

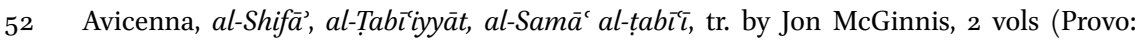
Brigham Young University Press, 2009), I.III.11, 365. The correspondence (tațiqq) argument was introduced by John Philoponus and reproduced in kalām (Davidson, Proofs, 88-9; 120-1).

53 Avicenna, al-Hukūma fì hujaj al-muthbitīn li-l-māậ̄ mabda’ zamānī, ed. by Mahdi Mohaghegh (Tehran: Mu’assasa-i muțālaāt-i islāmī, 1998), 142-4. A similar complaint seems to have been made by al-Fārābī (d. 339/950) in a lost work titled al-Mawjūdāt al-mutaghayyira (Maimonides, Dalālat al-ḥāirìn, ed. by Hüseyin Atay [Cairo: Maktabat al-thaqāfa al-dīniyya, n.d.], 220-1).

54 Avicenna, Țabīiyyāt, I.III.11, 366-7; cf. Hukūma, 144-6; 148-9; al-Mabda’ wa-l-ma'ād, ed. by 'Abdallāh Nūrānī (Tehran: Mu’assasa-i muțālacāt-i islāmī, Dānishgāh-i Tihrān, 1984), 47 .

55 Avicenna, Ilāhiyyāt, III.5, $119 \mathrm{ff.}$.; v.2, 212 ("a whole inasmuch as it is a whole exists in things"); Mohammad S. Zarepour, "Avicenna on the Nature of Mathematical Objects," Dialogue 55 (2016): 511-36.

56 Avicenna, Tabīìiyyāt, I.III.11, 365 . 
show their ignorance of the difference between each one and the whole, for when each thing is characterised by a certain attribute the whole need not be characterised by the same attribute, nor indeed must it have a realised whole. Were that the case, the whole would be a part, since each one is a part. Do they not ${ }^{57}$ see that each future thing is possible of existence, whereas their whole is not possible of existence! So it is not true what they said - namely, that when each one passes into actual existence, thus becoming realised, the whole does so as well and is therefore not infinite. The truth of the matter is as we stated-namely, that if ten finite things come into existence in succession, each after the passing away of another, then undoubtedly each one of these ten will actually have existed at some moment, whereas the whole will never have existed as something actual, for a whole such as this has, as a whole, no existence at all. ${ }^{58}$

Avicenna thus raises two objections to the mereological argument, both stated in the opening sentence. The first is the same as Ibn 'Adi's objection to the mereological principle - that when multiple individual items share a given attribute (sifa), their totality need not have the same attribute. He gives two pieces of counter-evidence (the third type of objection): each item is said to be a "part" $\left(j u z^{\prime}\right)$, whereas the whole is not; and even though future occurrences are each individually possible of existence, their totality is not possible of existence. For Avicenna's adversaries, the latter outcome follows from the notion that future occurrences are alternative possibilities, each of which may or may not exist: it is possible that the weather here be either clear or rainy at midday tomorrow, but it is impossible that it be both. What is more, theologians hold that although there is an infinite number of things possible of existence at each momentfor example, an infinite number of atoms-it is not possible that an infinite number of things exist at any moment. ${ }^{59}$

In his second objection, Avicenna differentiates between cases in which items add up to a totality and cases in which they do not (the invalidatingdifference objection). He references his general criticism of arguments against the pre-eternity of the world, which is that a series of things that come to be and pass away in succession does not have a real totality. Because the series of past successive motions does not have a totality in the first place, it cannot have

$57 \quad$ Reading a-là yarawna for wa-lā yarawna, as in the published editions.

$5^{8}$ Avicenna, Țabīiyyāt, I.III.11, 368-9 (based on McGinnis's excellent translation, with adjustments); cf. Mabda', 47 .

59 For Avicenna himself, future occurrences do not constitute a totality primarily because they will exist, not coevally, but in succession (táãqub) (Mabda', 47). 
an attribute in the way an individual object does. So even though each motion is originated, motions do not have a totality to which this same attribute can be extended.

In the sixth/twelfth century, Abū l-Barakāt al-Baghdādī launches a further attack on the proof from accidents, particularly on the mereological argument. His refutation is that the claim, 'because each motion is originated the totality of motions must be temporally initiated,' is merely an assertion (mușādara) of the conclusion of the proof. ${ }^{60}$ Even if each motion is originated, motion per se (mutlaq) need not be originated. So no contradiction is committed in asserting that the parts are originated while the totality is pre-eternal. ${ }^{61} \mathrm{Abu}$ l-Barakāt thus echoes earlier philosophical criticisms of the proof from accidents, here presented as a syllogism, by complaining that its middle term is equivocal: in the minor premise, 'cannot be devoid of what is originated (almuhdath)' means 'cannot be devoid of originated things per se,' whereas in the major premise it means 'cannot be devoid of a particular originated thing.' ${ }^{\prime} 2$

These criticisms are echoed in later philosophical literature, which need not be surveyed here. Both of Avicenna's objections are deployed. They are reproduced by Shihāb al-Dīn al-Suhrawardī (d. 587/1191), and it is partly, if not mainly, through his works and commentaries thereon that these objections appear to be transmitted to later philosophical sources. ${ }^{63}$

Of the objections advanced by philosophers and presumably by earlier eternalists the most problematic in classical kalām was the objection through counter-evidence, of which we may identify two types. Some attributes only hold for totalities but never for parts, or vice versa (e.g. 'set,' 'ten' and 'part'); other attributes may in principle hold for either parts or totalities, but often hold for the parts but not for their totality, or vice versa (as with the foregoing example of the possibility of future occurrences). Avicenna's objection from the non-coevality of the parts of a temporally-ordered series comes to the attention of theologians from around the turn of the sixth/twelfth century.

\footnotetext{
6o Abū l-Barakāt, Mu'tabar, 3, 31.

61 Abū l-Barakāt, Mu'tabar, 3, 45-6.

62 Abū l-Barakāt, Mu'tabar, 3, 31-2.

63 Al-Suhrawardī, Hịkmat al-ishrāq, ed. and trans. by John Walbridge and Hossein Ziai (Provo, UT: Brigham Young University Press, 1999), 120-1; Ibn Kammūna, Sharh al-Talwīhāt allawhiyya wa-l-'arshiyya, ed. by Najafqulī Ḥabībī, 3 vols (Tehran: Mīrāth-i maktūb, 20o9), 3, 275-6; Quṭb al-Dīn al-Shīrāzī, Sharh H Hikmat al-ishrāq, ed. by 'Abdallāh Nūrānī and Mahdī Muḥaqqiq (Tehran: Anjuman-i āthār u mafākhir-i farhangī, 200o), 393-4.
} 


\section{Theological Defences and Refutations of the Mereological Principle}

As already mentioned, Abū Hāshim al-Jubbā'̄ appears to have considered his early application of the mereological principle self-evident. Subsequent theologians had to develop and defend it under the sustained criticism that creation ex nihilo and the mereological argument continued to receive. Ibn alRāwandī, as noted, was often invoked as the principal advocate of the infinite regress thesis, but the criticisms advanced by Aristotelian philosophers were getting much attention already in the classical period. Abū l-Ḥusayn al-Bașrī, who was closely connected to Baghdad Aristotelianism, was aware of the previously discussed epistle in which Ibn 'Adī objected to the mereological argument, as in Tașaffuh al-adilla he quotes, and responds to, another passage from this work. ${ }^{64} \mathrm{~A}$ response to Ibn 'Adì's epistle, titled Fì l-radd 'alä Yahyā ibn 'Adī fì itirädihi dalìl al-muwahhidìn fì hadath al-ālam (A Response to Yahyā ibn 'Adī Concerning His Objections to the Theists' Proof for the Creation of the World), was also reportedly penned by al-Murtaḍā, an Imāmī whose core theological views were Bahshamī. ${ }^{65} \mathrm{Al}$-Murtaḍa wrote a further relevant response to Ibn 'Adī titled al-Kalām fí-mā yatanāhà wa-lā yatanāhā (On the Finite and the Infinite).${ }^{66}$ Neither text is known to be extant. Abū l-Husayn furthermore reports that he deployed the mereological principle in a debate he had with an unidentified adversary, most likely an Aristotelian, who failed to offer a satisfactory response. ${ }^{67}$ His contemporary Ibn Mattawayh ascribes the denial of the mereological principle to "some philosophers," most probably a reference to Baghdad Aristotelians. ${ }^{68}$ We therefore have ample evidence of a debate around the turn of the fifth/eleventh century between Baghdad Aristotelians and Mu'tazilīs surrounding the kaläm proof from accidents, and the mereological argument in particular.

It will be recalled that the argument cited in support of the mereological argument is an analogy, and that the most serious objection that this

64 Abū l-Ḥusayn al-Bașrī, Tașaffuh al-adilla, in al-Malāḥimī, Tuhfat al-mutakallimīn fí l-radd 'aläl-falāsifa, ed. by Hassan Ansari and Wilferd Madelung (Tehran: Iranian Institute of Philosophy, 2008), 32 (reading yalzamuhu for yulzimuhu, l. 6); cf. Ibn 'Adī, Maqāla fí l-radd, 230.

65 Al-Najāshī, Rijāl al-Najāshī, ed. by Mūsā al-Zanjānī (Qum: Mu’assasat al-nashr al-islāmī,

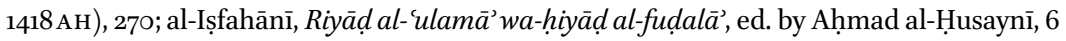
vols (Qum: Maktabat al-Khayyām, 1981), 4, 36.

66 Al-Murtaḍā, Mulakhkhaṣ, 62; al-Ișfahānī, Riyāụ, 4, 36.

67 Abū l-Ḥusayn, Tașaffuh, in al-Malāḥimī, al-Mutamad fì ușūl al-dīn, ed. by Wilferd Madelung (Tehran: Iranian Institute of Philosophy, 2007), 138.

68

Ibn Mattawayh, Majmū $c 66$. 
analogy faced in classical kaläm was the argument from counter-evidence. Theologians responded by developing the mereological principle from its allencompassing, universal formulation to a qualified formulation applicable to a much narrower scope of attributes.

The principle is qualified in accordance with classical-kaläm theories of attributes. At the most basic level, it operates only in the domain of the realities (haqāiq) of objects, ${ }^{69}$ as opposed to the linguistic and conceptual domains, which is to say that it applies only to real attributes (sifa thäbita) of objects. ${ }^{70}$ "Realities," al-Juwaynī writes, "do not differ in states of separation or combination" (al-haqā̄iq lā takhtalifu bi-l-infirād wa-l-ijtimāa). ${ }^{71}$ Mu'tazilī sources are more specific still, restricting its applicability to necessary attributes (șifa wäjiba) of existent objects, to the exclusion of possible attributes, which an object may or may not have on account of certain causes extraneous to itself. Although different schools of thought advocate different accounts of how these necessary attributes are realised, which we shall not go into here, the bottom line for our present purposes is broadly the same-namely, that a necessary attribute is one that an existent object cannot conceivably lack, be it an essential or non-essential attribute. Expressions that describe objects or states of affairs but do not meet this criterion fall outside the scope of the mereological principle.

Now, we know that, in classical-kaläm atomism, monads - that is, atoms and accidents-are attribute-bearing objects. But what of totalities? What is the ontological status of a totality, and to what extent do expressions that describe totalities refer to real attributes thereof? These questions are answered directly by al-Malāhimī at the start of his defence of creation ex nihilo against Avicenna in Tuhfat al-mutakallimin. Theologians and philosophers, he observes, mean different things when they speak of "the existence of the world." ${ }^{2}$ For philosophers, the combination of two things may produce a third, composite thing, which will exist neither as the mere "sum $\left(\right.$ majmu $\left.^{c}\right)$ of the parts, nor as each one (kull wähid) of them."73 A human, a building, a bed and the world thus exist each as a thing in its own right over and above its parts, just as oxymel has a reality of its own and exists over and above the sugar and vinegar of whose mixture it is produced. This notion is, of course, grounded in Peripatetic hylomorphism, according to which the form of the composite is one and unified and not the

69 Al-Juwaynī, Shāmil, 216-7.

70 We are obviously concerned here only with the attributes of objects other than God.

71 Al-Juwaynī, Shāmil, 217; see also the quote from al-Bāqillānī, p. 15 above.

72 Al-Malāḥimī, Tuhfa, 15.

73 Al-Malāhimì̄, Tuhfa, 16-7. 
mere sum of the forms of its parts-a notion given expression already in Aristotle's Metaphysics Z.17. In kalām, however, only the monadic parts exist-the atoms and the accidents — and only they are possessed of real attributes. Their combination will yield a body or bodies with a specific structure, for which an expression is conventionally assigned, but will not produce a thing that exists over and above its parts, or that itself bears any attributes. The existence of the totality is reducible to the existence of its parts, and its attributes are accordingly reducible to those of its parts. ${ }^{74}$ Oxymel is not a thing in its own right, but consists of a mixture of discrete parts of sugar and parts of vinegar. ${ }^{75}$ Theologians therefore infer the origination of the world immediately once they have proved the origination of its parts, because to them the world is nothing but the sum of its parts.

Based on the qualification that descriptive expressions whose referents are not real but merely conceptual fall outside the scope of the mereological principle, exponents of the principle were readily able to identify one category of expressions as having no bearing thereon. Some expressions are nouns that specifically denote totalities (ism jumla), and hence do not refer to attributes of individual parts. ${ }^{76}$ These include such expressions as 'ten,' 'man,' which is a name for the totality of parts that make up the human body, ${ }^{77}$ 'finite' and 'infinite. ${ }^{78}$ As just explained, these are designations conventionally assigned

74 Bahshamīs make an exception for animate attributes such as life and knowledge, which they hold to be reified attributes (sg. $h \bar{a} l$ ) that are caused by monadic accidents but nonetheless qualify the entire living body, in contrast to attributes that are not exclusive to living bodies, which only qualify an accident's atomist substrate (Richard M. Frank, Beings and Their Attributes: The Teaching of the Basrian School of the Mutazila in the Classical Period [Albany: State University of New York Press, 1978], 39 ff.; Ayman Shihadeh, "Classical Ash'arī Anthropology: Body, Life and Spirit," The Muslim World 102 (2012): 433-77, at 449-58, where the Ash'arī refutation of this view is also discussed). Animate attributes, however, do not engender a unifying essence for the composite body. The Bahshami theory of reified attributes is opposed by Abū l-Ḥusayn al-Bașrī and al-Malāḥimī. The latter only remarks that the totality may have an effect (ta'thir) that its parts lack when separate, although this must not be taken to imply that it has a reality distinct from its parts. (I translate $h \bar{a} l$ as 'reified attribute' to convey the meaning of the term, which is completely lost with the literal 'state'.)

75 In turn, both sugar and vinegar, of course, are no more than combinations of atoms and accidents (colour, taste, smell, etc.), and are not substances in their own right.

76 These are not always collective nouns (ism jam ${ }^{c}$ ), which are nouns that denote groups of individuals, such as qawm and jamāa $a$.

77 On classical-kalām conceptions of the human as a totality, see Shihadeh, "Classical Ash'arī Anthropology," $437 \mathrm{ff}$.

78 Abū Rashīd, Ziyādāt, 243; cf. Anonymous 1, 55-6; al-Jishumī, Sharh, foll. 258 ${ }^{\mathrm{a}-\mathrm{b}}$; al-Malāḥimī, Tuhfa, 2o. Strictly speaking, 'finite' (mutanāhī) means 'has a final part' (lahu nihāya) 
(mawd $\left.\bar{u}^{c}\right)$ to a totality, not as a unified attribute-bearing substance-al-Malāhịimī remarks that "ten, qua ten, does not bear a real attribute (șifa thäbita)"79_ but only inasmuch as the totality consists of specific monads arranged in a specific structure, which we are able to identify conceptually and linguistically as a particular type of totality. The structure is normally construed spatially as the shape of a body or bodies, but can presumably be temporal, as some expressions denote a sequence of temporally-ordered occurrences-for instance, 'prayer,' which is defined as the totality (jumla) of specific acts, 'week' and 'farming.' Either way, structure does not confer a reality on its parts, which they would otherwise lack. ${ }^{80}$ We commit no contradiction, therefore, when we speak of a totality as being infinite while denying that each of its parts is infinite. We can assume that by the same token designations that strictly signify parts inasmuch as they are parts cannot signify wholes. This qualification rebuts Avicenna's complaint that the expression 'part' applies to each part, but not to the whole.

In the same broad vein, al-Juwaynī addresses the oft-discussed counterexample of consensus $\left(i j m \bar{a}^{c}\right)$ or widely transmitted reports (tawātur), in which the reliability or veracity of the totality differs from that of individuals. ${ }^{81}$ Because the knowledge or belief that occurs in the listener after receiving a report has no correspondence to the reality of the (oral or written) report or the reporter, its reliability is not a real attribute either of the report or the reporter to which the mereological principle could apply. It is rather a function of God's will. The association of the two occurrences is grounded entirely in God's maintenance of familiar courses of events ('a $\bar{d} a$ ). Ordinarily, he does not create indubitable knowledge in listeners when they receive a report transmitted by a single transmitter, but he does create it when they receive a widely transmitted report. He can choose to break the familiar course of events by doing the reverse.

$\bar{a}$ khir), and hence can only be said of a set or the parts of a divisible thing (cf. p. 12 above on $a w w a l)$. To say that God is infinite (lā nihāya lahu) is a figure of speech, as strictly speaking it means that He does not have a final part, which presupposes that He has parts.

79 Al-Malāhịimī, Tuḥfa, 20.

8o The ontological sense of the expression haqiqa referred to here should not be confused with its sense when it is contrasted to 'figure of speech' (majazz). The latter is the sense intended when theologians, for instance, discuss haquiqat al-insān. They refer to the definition of the expression 'human,' not to some intrinsic reality of the human as an object.

81 See pp. 20-1 above. Al-Juwaynī, Shāmil, 216-7. Reading bi-haquīqa rājía for bi-haqüqatihi rājic (217, l. 5; Ms Istanbul, Fazll Ahmed Paşa, fol. 49' reads bi-ḥaqiqa rājic). The text from wa-idhā sabaqa ... bi-munqadin in the edition (ll. 7-13) was a marginal note, as the Ms copyist indicates, but was incorrectly incorporated by the editors into the main text. 
Addressing the same counter-example, Bahshamī Mu'tazilīs appeal to their qualification that the mereological principle applies only to necessary attributes to the exclusion of possible attributes. They argue that it does not operate when either of two types of possibility ( jawāz) identified by Abū Hāshim alJubbä'i is involved. ${ }^{82}$ The first is objective possibility, which lies in the power (qudra) of an agent to produce a thing. An infinite number of atoms are thus presently possible of existence inasmuch as they are power-objects (sg. maq$d \bar{u} r$ ) for God, and a limited range of objects are presently possible of existence as my power-objects. However, the totality of either of these sets of possibilities is presently impossible of existence. This is partly because they are alternative, and hence mutually exclusive, possibilities: although moving and not moving my right arm are each presently power-objects of mine, it is presently impossible for me both to move and not to move my right arm at the same time. Moreover, because God's power-objects are infinite, only a finite quantity can be actualised at any given moment. The second type of possibility is epistemic, or subjective possibility, which arises from doubt (shakk). Abū Rashīd gives two examples: for all I know, I deem it possible that each of the inhabitants of my city had lentil soup yesterday, or has forgotten that today is Tuesday, but I do not infer that it is possible that absolutely all inhabitants of the city had lentil soup yesterday, or do not know what day it is today. ${ }^{83}$ Another, curious example given in one source is that while we accept the possibility that each human may die at any given moment, we deem it impossible for their entirety to die at the same moment. ${ }^{84}$ In the same vein, the judgement that each individual is fallible expresses subjective possibility: because, for all we know, each individual may hold an erroneous view on a given question, we cannot be certain that Zayd will take the correct view if presented with the question. We cannot infer that the totality of the Muslim community will accordingly be susceptible to error. Therefore, it is not contradictory to accept the fallibility of individ-

82 Anonymous 1, 57; Abū Rashīd, Ziyādāt, 241. On this distinction as it is made by al-Juwaynī, evidently under Mu'tazilī influence, see Shihadeh, "Argument from Ignorance," 195-8.

83 Abū Rashīd, Ziyādāt, 241. The text mentions a food called mușabbara, which I have not been able to identify. Lentil soup is a fairly safe substitute.

84 Anonymous 1, 57. This example is treated as an instance of epistemic possibility because it is grounded in our ignorance of a living human's time of death, and indeed it works only if it is treated as such. But the example can also be analysed as a case of objective possibility, because death, theologians believe, is caused by God's power, and it is within His power to cause the death of any human at any moment. A Mu'tazilī would presumably concede that it is not impossible for God to cause all living humans to die simultaneously, and that He will actually do so on the Day of Judgment. 
ual believers while upholding the infallibility of the Muslim community on the basis of scriptural evidence, in the way that, according to our sources, it would be contradictory to assert the actual theological misbelief of individual non-believers while denying the theological misbelief of their entire community.

This Bahshamī qualification is criticised by their fellow Bașran Mu'tazilī Abū l-Husayn al-Bașrī in Tașaffuh al-adilla, the extensive but unfinished summa in which he evaluates his predecessors' arguments. He argues against the distinction that they make between real attributes and possibilities. ${ }^{85}$ Possibility in an existing thing, he says, is a real and necessary attribute thereof (al-jaw $\bar{a} z$ huwa al-șifa al-thābita, and jawāz dhālika wājib). Fallibility, the possibility of error ( jawāzal-khața), is a real attribute of each individual, and as such ought to be an attribute of their totality. The same is somehow true of God's power-objects. But exactly what Abu l-Husayn meant by affirming the reality of possibility is a question that goes beyond the purview of the present article and cannot be answered in our current state of knowledge of his theory of attributes, which was significantly different from the Bahshamī theory. At any rate, Abū l-Husayn goes on to proffer his own solution to the puzzle concerning consensus, arguing that it is a false counter-example, because consensus on a given view occurs, not when individuals are susceptible to error, before they affirm or deny the view, but only when they have all actually affirmed it. It thus accords with the mereological principle, because each believer holds the correct view, and so obviously does the community of believers. This raises the separate question of how individuals can become collectively infallible despite being individually fallible. Abū l-Husayn reasons that the properties $(h u k m)$ of an individual may depend on whether it exists in isolation or in association (iqtirān) with other individuals. When believers arrive at a view collectively, they do not err, presumably because God safeguards them from collective error. Likewise, taken on its own each power-object is possible of existence, but collectively the totality of the infinite number of God's power-objects is impossible of existence.

This attempt to salvage the mereological argument may appear to resonate with our foregoing observation that Abū l-Husayn adduces it in his earlier manual Ghurar al-adilla. By the time he penned the Tasaffuh, however, he had concluded that the mereological argument is unsound, for he goes on to say:

85 Abū l-Ḥusayn, Taṣaffuh, in al-Malāḥimī, Mu'tamad, 138 (reading infirādihi, at l. 13); Tuhfa, 21-2. 
I used this argument, which was adduced by our school-masters, in a discussion with one of our adversaries, who failed to respond to it with anything [worthy of mention]. However, it later became clear to me that it did not entail [its conclusion]. ${ }^{86}$

The adversary, as noted, is most likely an Aristotelian. The objection by which Abū l-Husayn himself accounts for his abandonment of the mereological argument is a further instance of the invalidating difference objection, as it points out a difference that invalidates the analogy with identically coloured bodies. ${ }^{87}$ The statement, 'all crows are black,' in fact reduces to the statement, 'each crow is black,' as there is no blackness of which the totality is possessed over and above that of individual crows, for the totality is nothing more than the sum of its parts. In contrast, the statement, 'the series of past motions is temporally initiated (lahu awwal), does not reduce to the statement, 'each motion is temporally initiated,' because the property predicated of individual motions in the latter statement is being originated (hâadith), which is to say that each motion becomes existent after it was non-existent, whereas the property predicated of the series of motions in the former statement is being initiated in an individual motion which no further motions pre-existed. ${ }^{88}$ There is, therefore, no correspondence between the two cases in the analogy. Along similar lines, Abū l-Ḥusayn takes issue with Abū Hāshim al-Jubbā'î's argument that to state that the series of past originated things is beginningless would be a contradiction. ${ }^{89}$

Abu l-Husayn, to my knowledge, is the first theologian in the classical period to reject the mereological principle. His objection is transmitted by his follower al-Malāhimì in the Mu'tamad, where the mereological argument is duly not endorsed but attributed to the Bahshamīs. In his later work, the Fã iq, alMalāhimī completely omits it. ${ }^{90}$ But by the time he writes his refutation of philosophy, Tuhfat al-mutakallimin, al-Malāhimì has reverted to his master's earlier position, offering a passionate defence of the mereological argument, which becomes his principal argument for the fourth thesis of the proof from accidents.

86 Abū l-Ḥusayn, Taṣaffuḥ, in al-Malāḥimī, Mu'tamad, 138.

87 Abū l-Ḥusayn, Tașaffuh, in al-Malāhimimī, Mu'tamad, 138-9 (the point is clear, despite what appears to be a textual corruption on p. 138, 1l. 20-1, specifically at nafy al-sawād 'an).

88 Cf. al-Malāhimī, Tuhfa, 2O-1, where the argument is reported without attribution. Reading lä bi-kawn for bi-kawn on p. 20, l. 24, and ta'tadda for ta'nada on p. 21, l. 3.

89 Abū l-Ḥusayn, Tașaffuḥ, in al-Malāḥimī, Mu'tamad, 85 .

9o Al-Malāhịimī, Mu'tamad, 138; Fã̉iq, 14-5. 
As for Avicenna's criticism of the mereological argument from the noncoevality of accidents, the first theologian to refer to it is al-Ghazālì (d. 505/1111), who appears to recognise its potency, and possibly accepts it. ${ }^{91} \mathrm{He}$ thus does not adduce the argument to substantiate the fourth thesis of the proof from accidents in his theological manual, the Iqtișād. ${ }^{92}$ The first rebuttal of Avicenna's objection seems to come from al-Ghazālì's follower Ibn Ghaylān al-Balkhī (d. ca. 590/1194), who wrote a response to Avicenna's aforementioned Huküma, titled Hudüth al-älam. He counters the objection by arguing that numbers, and therefore totalities, are purely conceptual (itibūrī): what exists extra-mentally are numerable individual objects, whereas numbers exist only in the mind. This is evidenced by the observation that we judge a totality to be, at once, one (an army) and multiple (soldiers); and because oneness and multiplicity are mutually exclusive, they cannot both exist in the same object, and therefore exist only in the mind. It follows that totalities can be coeval or non-coeval, for either way they are conceptual..$^{93}$ Ibn Ghaylān subsequently asserts the classical-kaläm mereological principle: unless a property is specific (khāṣs $)$ to individuals or totalities, it will transfer from the parts to their totality, be they, of course, coeval or non-coeval. ${ }^{94}$

Around the turn of the seventh/thirteenth century, Fakhr al-Dīn al-Rāzī offers further criticism of the mereological argument in some works, including the earlier Nihāyat al-uqūl and the later al-Matālib al-äliya. Like his older contemporary Ibn Ghaylān, al-Rāzī identifies Avicenna's objection from noncoevality as his principal objection to the mereological argument, and he rejects it as baseless. ${ }^{95}$ The general statement, "the totality of originated things

91 Al-Ghazālī, Tahāfut al-falāsifa, ed. by Maurice Bouyges (Beirut: Imprimerie Catholique, 1927), 33. He deploys Avicenna's criticism against the latter's appeal to mereology in his proof from possibility for the existence of God, although al-Ghazālī seems to misinterpret that part of the proof effectively as an application of the kaläm mereological principle, which it is not (Tahäfut, 138-42). Al-Malāhimī does the same (Tuḥfa, 42-3).

92 Al-Ghazālī, Iqtișād, 31-4; cf. al-Risāla al-qudsiyya, ed. by Abdel Latif Tibawi, in "Al-Ghazālì's Sojourn in Damascus and Jerusalem," Islamic Quarterly 9 (1965): 65-122, at 81.

93 Ibn Ghaylān, Hudūth, 25-6.

94 Ibn Ghaylān, Hudūth, 36 . He mentions the proof from accidents, including the mereological argument, but considers it ineffectual against the philosophers' eternalism and hence does not take it forward (Hudūth, 15-6; Ayman Shihadeh, "A Post-Ghazālian Critic of Avicenna: Ibn Ghaylān al-Balkhī on the Materia Medica of the Canon of Medicine," Journal of Islamic Studies 24 (2013): 135-74, at 143-4).

95 Fakhr al-Dīn al-Rāzī, al-Mațālib al-āliya min al-iilm al-ilāhī, ed. by Aḥmad Ḥ. al-Saqqā, 8 parts in 5 vols (Beirut: Dār al-kitāb al-'arabī, 1987), 4, 253-4; 262-3. Al-Rāzī was aware of Avicenna's Hukūma, as he read Ibn Ghaylān's Hudūth al-älam and appears to have written a response to the latter (Shihadeh, "Post-Ghazālian Critic," 146). 
existed,' holds true whether those things existed simultaneously (bi-șifat alijtima $\bar{a}^{c}$ ) or separately and successively (bi-sifat al-iftirāq wa-l-tacāqub). If I say that I met all the town's inhabitants, you may legitimately ask whether I met them all at once or individually. Avicenna, according to al-Rāzī, fails to justify his restricted definition of 'totality.'

Al-Rāzī, nonetheless, rejects the standard kalām argument by analogy with the case of identically coloured bodies as flawed on two counts. ${ }^{96}$ The first (an objection from counter-evidence) is that such analogies go no further than to illustrate that at least some wholes bear the same attributes as their parts, and thus fall short of establishing the universal applicability of the mereological principle to all cases, for which further proof is needed. ${ }^{97} \mathrm{He}$ cites counterevidence showing that wholes in fact need not bear the same attributes as their parts, including some drawn from earlier sources. For instance, if something is said to be a 'part' it is not said to be a 'whole', the community is infallible although individuals are fallible, and it is possible for each location-accident (sg. kawn) not to exist in a given body but impossible for all location-accidents to be absent therefrom. ${ }^{98} \mathrm{Al}-\mathrm{Ra} z \bar{z}$ does not address Bașran Mu'tazilī rebuttals to such counter-evidence. The second objection (an invalidating difference objection) is that there is a key difference between the two cases of the analogy adduced. However, the difference he identifies is epistemic: while it is immediately evident (darūrī) that the totality of black crows must be black, it is not equally evident that the totality of temporally initiated things must itself be temporally initiated. This indicates that the two cases are not equivalent, or at least that further work is needed to establish their equivalence.

Yet despite his opposition to the classical-kalām mereological argument, alRāzī proposed a new argument inspired by Avicenna's account of quiddity (mähiyya), which was treated in many later sources as a reformulation of the mereological argument. He counters the infinite regress thesis by arguing that the quiddity of motion cannot be pre-eternal, as follows:

The reality and quiddity of motions is transition from one state to another. So motion is preceded by the state away from which the transition occurred. Therefore, the reality of motion entails precededness (mas-

96 Al-Rāzī, Nihāya, 1, 343-4; Mațālib, 4, 277-8; al-Mabāhith al-mashriqiyya, ed. by Zayn al'Ābidīn al-Mūsawī et al., 2 vols (Hyderabad: Dā’irat al-ma'ārif al-'uthmāniyya, 1343AH), 1, $666 ; 668-9$ (the first objection only).

97 This tallies with al-Rāzì's assessment that arguing from analogy is inadequate for the purposes of theology and philosophy (Nihāya, 1, 133-6).

98 Location-accidents are accidents that determine the location of an atom. 
büqiyya) by another. However, the reality of pre-eternity (azaliyya) does not entail precededness by another. Therefore, it is impossible for motion and pre-eternity to coincide. ${ }^{99}$

Al-Rāzī considers the conception of precededness by a prior state to be entailed by the quiddity of motion as a constitutive thereof, and hence to hold for motion per se and not merely for individual motions. ${ }^{100}$ And because the quiddity of motion is realised extramentally through its concrete instantiations, precededness must hold for their entirety, which is to say that they must be preceded by non-motion and consequently that it is impossible for motions to regress infinitely a parte ante. The upshot is that this argument converges with the classical-kaläm mereological argument by effectively extending a property of the individuals to their totality. The later debate that surrounded this controversial argument goes beyond our present purposes. ${ }^{101}$ Suffice it to point out, however, that al-Rāzī's new argument is just as susceptible as the traditional mereological argument to the objection that while conceptions constitutive of a quiddity hold necessarily for particular instantiations thereof, they do not hold necessarily for the totality of instantiations.

The mereological argument continued to be debated up to the early-modern period. The classical-kalām argument and variants of al-Rāzì's argument are adduced in many later theological sources and confuted in others and in philosophical sources. Of particular interest is Ibn Taymiyya, who takes al-Rāzì's criticism of the mereological argument to heart and develops it further in his attack on refutations of infinite regress, through which he counters the kaläm notion that God had been an inactive agent for an eternity until he created the

99 Fakhr al-Dīn Al-Rāzī, al-Masā̄il al-khamsūn fì uṣūl al-dīn, ed. by Ahmad Ḥ. al-Saqqā (Beirut: Dār al-jīl, 199o), 19; cf. Muḥașșal afkār al-mutaqaddimīn wa-l-muta’akhkhirīn min al-ḥukamā’ wa-l-mutakallimīn, ed. by Hüseyin Atay (Cairo: Maktabat dār al-turāth, 1991), 286; Kitāb al-Arbaìn fì ușūl al-dīn, ed. by Aḥmad Ḥ. al-Saqqā, 2 vols (Cairo: Maktabat al-kulliyyāt al-azhariyya, 1986), 1, 32-3; Ma'ālim ușūl al-dīn, ed. by Ṭāha 'A. Sacd (Cairo: Maktabat al-kulliyyāt al-azhariyya, n.d.), 35 .

100 Al-Rāzī, Muḥașsal, 293; 297-8.

101 Representative exponents: al-Ijjī, al-Mawāqiffí 'ilm al-kalām (Beirut: 'Ālam al-kutub, n.d.), 246; al-Taftāzānī, Sharh al-Maqāṣid, ed. by 'Abd al-Raḥmān 'Umayra, 5 vols (Beirut: 'Ālam al-kutub, 1998), 3, 109-13. Representative opponents: al-Qarāīi, Sharh al-Arbaīin fì ușūl aldīn, ed. by Nizār Ḥammādī (Cairo: Dār al-așāla, 2020), 45-6; Nașīr al-Dīn al-Ṭūsī, Talkhịs alMuḥașșal (Beirut: Dār al-aḍwā', 1985), 198; al-Kātibī, Hikmat al-'ayn, ed. by Ṣālị̣ A. al-Turkī (n.p., 2002), 52 (reading lā yunāfì for yunāfí, l. 19); al-Dawānī, Sharh al-'Aqā̉id al-'Adududiyya (Cairo: Maktabat al-shurūq al-dawliyya, 2002), 49; Gelenbevi, Ḥāshiya 'alā Sharh al-'Aqā’id

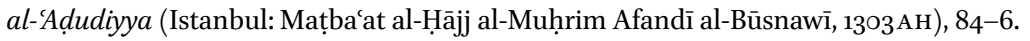


world. ${ }^{102}$ At any rate, although it continues to be adduced and contested, the mereological argument somewhat diminished in significance with the development of further proofs for creation ex nihilo and against the infinite regress thesis.

\section{Bibliography}

'Abd al-Jabbār ibn Aḥmad, al-Qāḍī. Al-Mughnī fì abwāa al-tawhīd wa-l-'adl, 8. alMakhlūq. Ed. by Tawfīq al-Ṭawīl and Saīd Zāyid. Cairo: al-Dār al-mișriyya li-l-ta'līf wa-l-tarjama, 1965 .

'Abd al-Jabbār ibn Aḥmad, al-Qāậ̄. Al-Mukhtaṣar fì uṣūl al-dìn. In Rasāill al-'adl wa-ltawhīd. Ed. by Muḥammad 'Amāra. 2 vols. Cairo: Dār al-shurūq, 1988, 1: 197-282.

Abū l-Barakāt al-Baghdādī, Hibat Allāh ibn 'Alī. Al-Mu'tabar fí l-hikma. Ed. by 'Abdallāh al-Alawī al-Ḥaḍramī et al. 3 vols. Hyderabad: Dāirat al-macārif al-'uthmāniyya, $1357 \mathrm{AH}$.

Abū Rashīd al-Nīsābūrī. Ziyādāt al-Sharh [published as Fī l-tawhịd]. Ed. by Muḥammad 'A. Abū Rīda. Cairo: al-Mu’assasa al-mișriyya al-cāmma li-l-ta'līf wa-l-tarjama wa-l-țibāa wa-l-nashr, 1969 .

[Anonymous 1. Untitled fragments, on which see fn. 5 above]. In Al-Sāhib Ibn Abbād Promoter of Rational Theology: Two Mu'tazilī kalām Texts from the Cairo Geniza. Ed. by Wilferd Madelung and Sabine Schmidtke. Leiden: Brill, 2017, 27-83.

Anonymous 2. Sharh Kitāb al-Tadhkira fì ahkām al-jawāhir wa-l-áräḍ. Facsimile edition with introduction by Sabine Schmidtke. Tehran: Iranian Institute of Philosophy, 2006.

Al-Anșāīi, Abū l-Qāsim Salmān. Al-Ghunya fí l-kalām. Ed. by Muștafā Ḥ. 'Abd al-Hādī. 2 vols. Cairo: Dār al-salām, 2010.

Al-Ash`arī, Abū l-Ḥasan 'Alī ibn Ismāīil. Maqāalāt al-islāmiyyūn. Ed. by Helmut Ritter. Wiesbaden: Franz Steiner, 1980.

Averroes (Ibn Rushd, Abū l-Walīd Muhammad ibn Aḥmad). Al-Kashf 'an manāhij aladilla fì 'aqā̉id al-milla. Ed. by Muhammad 'A. al-Jābirī. Beirut: Markaz dirāsāt alwaḥda al-arabiyya, 1998.

Avicenna (Ibn Sīnā, al-Ḥusayn ibn 'Abdallāh). Al-Shifäa', al-Ilāhiyyāt. Ed. by Georges

102 Ibn Taymiyya, Dar', 9, 137-47; Minhāj al-sunna al-nabawiyya fì l-radd 'alā kalām al-shīa al-qadariyya, ed. by Muhammad R. Sālim, 9 vols (Riyadh: Jāmi‘at al-Imām Muhammad ibn Sa'ūd al-islāmiyya, 1986), 1, 426-32. Other, shorter discussions are found elsewhere in his oeuvre. Ibn Taymiyya, who did not have access to Abū l-Ḥusayn's Tașaffuh, ironically names him as the arch-advocate of the mereological argument, and al-Rāzī as its archopponent. 
Anawati and Sa'̄id Zāyid. 2 vols. Cairo: Wizārat al-thaqāfa wa-l-irshād al-qawmī, 196o.

Avicenna (Ibn Sīnā, al-Ḥusayn ibn 'Abdallāh). Al-Ta'līqāt. Ed. by 'Abd al-Raḥmān Badawī. Cairo: al-Hay’a al-mișriyya al-'āmma li-l-kitāb, 1973.

Avicenna (Ibn Sīnā, al-Ḥusayn ibn 'Abdallāh). Al-Mabda'wa-l-ma`ād. Ed. by 'Abdallāh Nūrānī. Tehran: Mu’assasa-i muțāla'āt-i islāmī, Dānishgāh-i Tihrān, 1984.

Avicenna (Ibn Sīnā, al-Ḥusayn ibn 'Abdallāh). Al-Hukūma fì hujaj al-muthbitīn li-l-māḍ̄ mabda'zamānī. Ed. by Mahdi Mohaghegh. Published together with Ibn Ghaylān alBalkhī's Hudūth al-'ālam. Tehran: Mu’assasa-i muțāla'āt-i islāmī, 1998.

Avicenna (Ibn Sīnā, al-Ḥusayn ibn 'Abdallāh). The Physics of the Healing [=al-Shifä', alTabīizyyāt, I. al-Samā'al-țabīì]. Trans. by Jon McGinnis. 2 vols. Provo: Brigham Young University Press, 2009 .

Al-Baghdādī, Abū Manșūr 'Abd al-Qāhir. Ușūl al-dīn. Istanbul: Madrasat al-ilāhiyyāt bidār al-funūn al-turkiyya, 1928.

Brunschvig, Robert. "Ğāmic Māni`." In Études d'islamologie. Ed. by Abdel Magid Turki. 2 vols. Paris: Éditions Larose, 1976, 2: 355-7.

Al-Buṭ̣ān̄̄, Abū Ṭālib Yaḥyā ibn al-Ḥusayn. Ziyādāt Sharḥ al-uṣūl. Ed. by Camila Adang, Wilferd Madelung and Sabine Schmidtke. Leiden: Brill, 2011.

Davidson, Herbert A. Proofs for Eternity, Creation, and the Existence of God in Medieval Islamic and Jewish Philosophy. New York: Oxford University Press, 1987.

Al-Dawānī, Jalāl al-Dīn Muḥammad ibn As'ad. Sharḥ al-'Aqā’id al-'Adudiyya. Published together with Jamāl al-Dīn al-Afghānī's and Muhammad Abduh's al-Ta līqāt 'alā Sharh al-Dawānī li-l-'Aqā̉id al-'Aḍdiyya. Cairo: Maktabat al-shurūq al-dawliyya, 2002.

El Omari, Racha. The Theology of Abū l-Qāsim al-Balkhī/al-Ka'bì (d. 319/931). Leiden: Brill, 2016.

Ess, Josef van. Theology and Society in the Second and Third Centuries of the Hijra. Vol. 3. Trans. by Gwendolin Goldblum. Leiden: Brill, 2017.

Frank, Richard M. Beings and Their Attributes: The Teaching of the Basrian School of the Mu'tazila in the Classical Period. Albany: State University of New York Press, 1978.

Gelenbevi, Ismāêll ibn Muṣțafā. Hāshiya 'alā Sharh al-'Aqāid al-Aḍudiyya. Istanbul: Maṭba'at al-Ḥājj al-Muḥrim Afandī al-Būsnawī, 1303AH.

Al-Ghazālī, Abū Ḥāmid. Tahāfut al-falāsifa [Tahâfot al-Falâsifat ou Incohérence des Philosophes']. Ed. by Maurice Bouyges. Beirut: Imprimerie Catholique, 1927.

Al-Ghazālī, Abū Ḥāmid. Al-Iqtiṣād fì l-ítiqād. Ed. by Ibrāhīm A. Çubukçu and Hüseyin Atay. Ankara: Nur matbaasi, 1962.

Al-Ghazālī, Abū Ḥāmid. Al-Risāla al-qudsiyya. Ed. by Abdel Latif Tibawi in "Al-Ghazālī's Sojourn in Damascus and Jerusalem." Islamic Quarterly 9 (1965): 65-122.

Gimaret, Daniel. La Doctrine d'al-Ash'arī. Paris: Cerf, 2007.

Al-Harrāsī, al-Kiyā. Ușūl al-Dīn. Ms Cairo, Dār al-Kutub al-Mișriyya, Kalām 290. 
Ibn 'Adī, Yaḥyā. Maqāla fì l-kull wa-l-ajzā'. Ed. by Saḥbān Khulayfāt in Maqālāt Yahyāa ibn 'Adī al-falsafiyya. Amman: University of Jordan, 1988, 212-19.

Ibn 'Adī, Yahyā. Maqāla fì l-radd 'alā man qāla bi-anna l-ajsām muḥdatha. Ed. and trans. by Peter Adamson and Robert Wisnovsky in "Yahyyā Ibn 'Adī on a Kalām Argument for Creation." Oxford Studies in Medieval Philosophy 5 (2017): 213-39.

Ibn Ghaylān al-Balkhī, 'Umar ibn 'Alī. Hudūth al-'álam. Ed. by Mahdī Muhaqqqiq. Tehran: Mu’assasa-i muṭāla'āt-i islāmī, 1998.

Ibn Ḥazm, Abū Muḥammad 'Alī ibn Aḥmad. Al-Fịsalfíl-milalwa-l-ahwä’wa-l-niḥal. Ed. by Muḥammad I. Nașr and 'Abd al-Raḥmān 'Umayra. 5 vols. Beirut: Dār al-jīl, 1996.

Ibn Kammūna, 'Izz al-Dawla Sa'd ibn Manșūr. Sharh al-Talwīhāt al-lawhiyya wa-l'arshiyya. Ed. by Najafqulī Habībī. 3 vols. Tehran: Mīrāth-i maktūb, 2009.

Ibn Mattawayh, al-Ḥasan ibn Aḥmad. [Al-Majmūc fì] l-Muḥịt bi-l-taklïf. Vol. 1. Ed. by 'Umar S. 'Azmī. Cairo: al-Dār al-mișriyya lil-ta'līf wa-l-tarjama, [1965].

Ibn Mattawayh, al-Ḥasan ibn Aḥmad. Al-Tadhkira fı ahkām al-jawāhir wa-l-a'rāẹ. Ed. by Daniel Gimaret. 2 vols. Cairo: Institut français d' archéologie orientale, 2009.

Ibn Suwār, Abū l-Khayr al-Hasan. Maqāla fì anna dalīl Yahyā al-Naḥw̄̄ 'alà hadath al'àlam awlā bi-l-qabūl min dalīl al-mutakallimin așlan. In al-Aflāțūniyya al-muḥdatha 'inda l-'arab. Ed. by 'Abd al-Raḥmān Badawī. Kuwait:Wikālat al-maṭbū'āt, 1977, 2437.

Ibn Taymiyya, Taqī al-Dīn Aḥmad. Minhāj al-sunna al-nabawiyya fí l-radd 'alā kalām al-shĩa al-qadariyya. Ed. by Muhammad R. Sālim. 9 vols. Riyadh: Jāmi'at al-Imām Muhammad ibn Sacūd al-islāmiyya, 1986.

Ibn Taymiyya, Taqī al-Dīn Aḥmad. Dar' ta'āruḍ al-'aql wa-l-naql. Ed. by Muḥammad R. Sālim. 11 vols. Riyadh: Jāmi‘at al-Imām Muhammad ibn Sa‘uud al-islāmiyya, 1991. Al-Ījīi, 'Aḍud al-Dīn. Al-Mawāqif fì ilm al-kalām. Beirut: 'Ālam al-kutub, n.d.

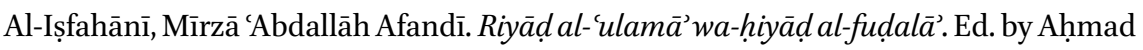
al-Husaynī. 6 vols. Qum: Maktabat al-Khayyām, 1981.

Al-Jishumī, al-Muḥassin ibn Muḥammad al-Ḥākim. Sharh 'Uyūn al-masā̉il. Ms Sanaa, al-Jāmi` al-kab̄ir, al-Maktaba al-gharbiyya.

Al-Juwaynī, Imām al-Ḥaramayn 'Abd al-Malik ibn Yūsuf. Kitāb al-Irshād ilā qawāți' aladilla fì uṣūl al-i'tiqād. Ed. by Muḥammad Mūsā and 'Alī 'Abd al-Hạīì. Cairo: Maktabat al-Khānjī, 1950.

Al-Juwaynī, Imām al-Ḥaramayn ‘Abd al-Malik ibn Yūsuf. Al-Shāmilfì uṣūl al-dīn. Ed. by 'Alī S. al-Nashshār, Fayṣal B. 'Awn and Suhayr M. Mukhtār. Alexandria: Munsha’at al-ma'ārif, 1969.

Al-Juwayn̄̄, Imām al-Ḥaramayn 'Abd al-Malik ibn Yūsuf. Luma' al-adilla fì qawā'id 'aqā’id ahl al-sunna wa-l-jamā'a. Ed. by Fawqiyya Ḥ. Maḥmūd. Beirut: 'Ālam al-kutub, 1987.

Al-Juwaynī, Imām al-Ḥaramayn 'Abd al-Malik ibn Yūsuf. Al-Shāmil fì ușūl al-dīn. MS Istanbul, Fazıl Ahmed Paşa. 
Al-Ka'bī, Abū l-Qāsim 'Abdallāh ibn Aḥmad. Kitāb Maqālāt. Ed. by Hüseyin Hansu, Rājị̣ Kurdī and 'Abd al-Ḥamīd Kurdī. Istanbul: Kuramer, 2018.

Al-Karājakī, Abū l-Fatḥ Muhammad ibn 'Alī. Kanz al-fawāìd. Ed. by 'Abdallāh Ni'ma. 2 vols. Beirut: Dār al-aḍwā', 1985 .

Al-Kātibī, Najm al-Dīn 'Alī ibn 'Umar. Hikmat al-'ayn. Ed. by Ṣāliḥ A. al-Turkī. N.p., 2002.

Al-Khayyāț, Abū l-Ḥusayn 'Abd al-Raḥimm ibn Muhammad. Kitāb al-Intiṣār. Ed. by Albert N. Nader. Beirut: al-Mațba'a al-kathūlīkiyya, 1957.

Maimonides, Mūsā. Dalālat al-hạ̄irīn. Ed. by Hüseyin Atay. Cairo: Maktabat al-thaqāfa al-dīniyya, n.d.

Al-Malāḥimī, Rukn al-Dīn Maḥmūd ibn Muḥammad. Al-Fã̄iq fì uṣūl al-dīn. Ed. by Wilferd Madelung and Martin McDermott. Tehran: Iranian Institute of Philosophy, 2007.

Al-Malāḥimī, Rukn al-Dīn Maḥmūd ibn Muḥammad. Al-Mútamadfı́uṣūl al-dīn. Ed. by Wilferd Madelung. Tehran: Iranian Institute of Philosophy, 2007.

Al-Malāḥimī, Rukn al-Dīn Maḥmūd ibn Muḥammad. Tuḥfat al-mutakallimīn fí l-radd 'alā l-falāsifa. Ed. by Hassan Ansari and Wilferd Madelung. Tehran: Iranian Institute of Philosophy, 2008.

Mānkdīm Shashdīw. Sharh al-uṣūl al-khamsa. Ed. by 'Abd al-Karīm 'Uthmān. Cairo: Maktabat Wahba, 1965.

Al-Māwardī, Abū l-Ḥasan 'Alī ibn Muhạmmad. A'lām al-nubuwwwa. Beirut: Dār al-kutub al-ilmiyya, 1986.

Al-Murtaḍā, al-Sharīf 'Alī ibn al-Ḥusayn. Amālī. Ed. by Muḥammad A. Ibrāhīm. 2 vols. Cairo: '̄̄sā al-Bābī al-Halabī, 1954.

Al-Murtaḍā, al-Sharīf 'Alī ibn al-Ḥusayn. Al-Mulakhkhas fì uṣūl al-dīn. Ed. by Muhammad R. Qummī. Tehran: Markaz-i nashr-i dānishgāhī, 2002.

Al-Najāshī, Aḥmad ibn 'Alī. Rijāl al-Najāshì. Ed. by Mūsā al-Zanjānī. Qum: Mu’assasat al-nashr al-islāmī, 1418 AH.

Pines, Shlomo. Studies in Arabic Versions of Greek Texts and in Medieval Science. Jerusalem: The Magnes Press, 1986.

Al-Qarāfī, Shihāb al-Dīn Aḥmad ibn Idrīs. Sharḥ al-Arbaīn fì uṣūl al-dīn. Ed. by Nizār Hammādī. Cairo: Dār al-aṣāla, 2020.

Al-Rāzī, Fakhr al-Dīn Muhammad ibn 'Umar. Al-Mabāhith al-mashriqiyya. Ed. by Zayn al-'Ābidīn al-Mūsawī et al. 2 vols. Hyderabad: Dāirat al-ma‘āif al-'uthmāniyya, 1343AH.

Al-Rāzī, Fakhr al-Dīn Muḥammad ibn 'Umar. Kitāb al-Arba'ìn fì ușūl al-dīn. Ed. by Aḥmad Ḥ. al-Saqqā. 2 vols. Cairo: Maktabat al-kulliyyāt al-azhariyya, 1986.

Al-Rāzī, Fakhr al-Dīn Muḥammad ibn 'Umar. Al-Mațālib al-'āliya min al-ílm al-ilāhì. Ed. by Aḥmad Ḥ. al-Saqqā. 8 parts in 5 vols. Beirut: Dār al-kitāb al-'arab̄̄i, 1987.

Al-Rāzī, Fakhr al-Dīn Muḥammad ibn 'Umar. Al-Masā̉il al-khamsūn fí uṣūl al-dīn. Ed. by Aḥmad Ḥ. al-Saqqā. Beirut: Dār al-jīl, 1990. 
Al-Rāzī, Fakhr al-Dīn Muḥammad ibn 'Umar. Ma`ālim uṣūl al-dīn. Ed. by Țāha 'A. Sa'd. Cairo: Maktabat al-kulliyyāt al-azhariyya, n.d.

Al-Rāzī, Fakhr al-Dīn Muḥammad ibn 'Umar. Muḥașal afkār al-mutaqaddimīn wa-lmuta’akhkhirīn min al-ḥukamā’ wa-l-mutakallimīn. Ed. by Hüseyin Atay. Cairo: Maktabat dār al-turāth, 1991.

Al-Rāzī, Fakhr al-Dīn Muhammad ibn 'Umar. Nihāyat al-'uqūl fídirāyat al-uṣūl.Ed.Sa'ìd 'A. Fūda. 5 vols. Beirut: Dār al-dhakhāir, 2015.

Al-Rāzī, Fakhr al-Dīn Muhammad ibn 'Umar. Ușūl al-Dīn. Ms Beirut, American University of Beirut Library, 297:R27kA.

Shihadeh, Ayman. "Existence of God." In The Cambridge Companion to Classical Islamic Theology. Ed. by Tim Winter. Cambridge: Cambridge University Press, 2008, 197-217.

Shihadeh, Ayman. "Classical Ash'arī Anthropology: Body, Life and Spirit." The Muslim World 102 (2012): 433-77.

Shihadeh, Ayman. "The Argument from Ignorance and Its Critics in Medieval Arabic Thought." Arabic Sciences and Philosophy 23 (2013): 171-220.

Shihadeh, Ayman. "A Post-Ghazālian Critic of Avicenna: Ibn Ghaylān al-Balkhī on the Materia Medica of the Canon of Medicine." Journal of Islamic Studies 24 (2013): 13574.

Shihadeh, Ayman. Doubts on Avicenna: A Study and Edition of Sharaf al-Dīn al-Mas'ūdìs Commentary on the Ishārāt. Leiden: Brill, 2016.

Shihadeh, Ayman. "Al-Rāzī's Earliest Kalām Work: Eastern Ash'arism in the Twelfth Century." In Philosophical Theology in Islam: Later Ash'arism East and West. Ed. by Ayman Shihadeh and Jan Thiele. Leiden and Boston: Brill, 2020, 36-70.

Al-Shīrāzī, Quṭb al-Dīn. Sharh Hikmat al-ishrāq. Ed. by 'Abdallāh Nūrānī and Mahdī Muḥaqqiq. Tehran: Anjuman-i āthār u mafākhir-i farhangī, 2000.

Al-Suhrawardī, Shihāb al-Dīn Yahyyā ibn Habash. The Philosophy of Illumination [= Hịkmat al-ishrāq]. Ed. and trans. by John Walbridge and Hossein Ziai. Provo, UT: Brigham Young University Press, 1999.

Al-Taftāzānī, Sa'd al-Dīn Mas'ūd ibn 'Umar. Sharḥ al-Maqāṣid. Ed. by 'Abd al-Raḥmān 'Umayra. 5 vols. Beirut: 'Ālam al-kutub, 1998.

Al-Ṭūsī, Abū Jađar Muhammad ibn al-Ḥasan. Tamhīd al-uṣūl. Qum: al-Markaz al-takhașṣuṣi li-cilm al-kalām al-islāmī, 2016.

Al-Ṭūsī, Nașīr al-Dīn Muḥammad b. Muḥammad. Talkhịs al-Muḥaṣṣal. Beirut: Dār alaḍ̂ā', 1985 .

Young, Walter E. The Dialectical Forge:Juridical Disputation and the Evolution of Islamic Law. Cham: Springer, 2017.

Zarepour, Mohammad S. "Avicenna on the Nature of Mathematical Objects." Dialogue $55(2016): 5^{11-36 .}$ 